\title{
Problems in Human Rights and Large Dams
}

Dinah L. Shelton

George Washington University Law School, dshelton@law.gwu.edu

Donald K. Anton

Follow this and additional works at: https://scholarship.law.gwu.edu/faculty_publications

Part of the Law Commons

\section{Recommended Citation}

Shelton, Dinah L. and Anton, Donald K., "Problems in Human Rights and Large Dams" (2011). GW Law Faculty Publications \& Other Works. 1075.

https://scholarship.law.gwu.edu/faculty_publications/1075

This Article is brought to you for free and open access by the Faculty Scholarship at Scholarly Commons. It has been accepted for inclusion in GW Law Faculty Publications \& Other Works by an authorized administrator of Scholarly Commons. For more information, please contact spagel@law.gwu.edu. 


\title{
Donald K. Anton \& Dinah SHELton, EnVironmental Protection and Human Rights (Cambridge Univ. Press, 2011)
}

\author{
Large Dams Case Study
}

Among large infrastructure projects, damming rivers to provide hydroelectric power have been the source of considerable conflict between governments and the people who are affected by such projects, especially those forced to relocate. In many instances dams are built in pristine natural areas, destroying or degrading nature reserves, indigenous lands and/or archaeological sites. Increasing opposition to large dams has resulted in national and international litigation, as well as substantial changes in the practices of international financial institutions. This case study looks at the case of the Narmada dam in India, as it has evolved over time in response to public action, national litigation, and challenges to World Bank financing. In reading these materials, consider the following issues:

(1) In developing countries, do the benefits of flood control and the provision of renewable energy outweigh the environmental and human rights impacts of large dams?

(2) Can equal or greater benefits be achieved by alternative development projects that have fewer negative impacts on the environment and human rights?

(3) By what procedures and substantive measures can the negative impacts by avoided or mitigated?

(4) Even if there are considerable benefits to hydroelectric projects, should certain locations be off-limits to the construction of large dams? If so, what are the relevant criteria by which to decide?

(5) How should the rights of local communities and indigenous populations be safeguarded?

\author{
Large Dams-The End Of An Era? \\ Peter Coles, The UNESCO Courrier, April 2000
}

At the last count, there were around 40,000 large dams on the world's rivers, according to the International Commission on Large Dams (ICOLD). ${ }^{1}$ Most of them were built in the last 35 years. A further 1,600 are under construction in over 40 countries. But is the era of building very large dams coming to an end? Pressure groups of displaced rural communities and ecology organizations have already disrupted dam building in the United States and India....

For ICOLD, the links between dam building and development are obvious. Two prerequisites for the development of a nation are energy and water, says one ICOLD paper. But since these resources are most scarce precisely where demand is rising most rapidly, dams have become almost synonymous with development. So, while dam building in developed countries has slowed to a trickle in the last decade, major constructions are underway in industrializing countries, like China's massive Three Gorges project and India's Narmada Valley Development project. Over half of all large dams (more than 22,000) are in China, while India has become the third largest dam constructor in the world, with over 3,000 large dams.

Although dams produce power without contributing to the greenhouse effect-about 20 per cent of world electricity and seven per cent of all energy, according to ICOLD - their primary purpose is water control. Reservoirs can provide drinking water, while smoothing out the "boom and bust" cycles of flooding and drought brought about by monsoons. They do this by storing excess water in reservoirs during the rainy season and releasing it in times of scarcity. But by far the greatest use of

\footnotetext{
1 ICOLD, founded in 1928, seeks to advance the art and science of dams. It has some 6,000 individual members and National Committees in 80 countries. ICOLD defines a large dam as one that is over 15 metres high.
} 
dams is to supply irrigation water for agriculture. In developing countries, according to the United Nations Environment Programme (UNEP), irrigation accounts for over 75 per cent of water consumption. In some countries, the figure is over 90 per cent.

At present, according to ICOLD, one third of all food produced already comes from irrigated land. And the organization sees irrigation as the only way to meet the future increase in demand, expecting 80 per cent of food production to come from irrigated land by 2025 .

But the case for irrigation is far from clear-cut. According to the International Rivers Network (IRN), a non-governmental organization, irrigation canals cause eutrophication ${ }^{2}$. Meanwhile, the crops produced are often for export and do not feed the sectors of the population that are expanding most rapidly - the poor. And ironically, these are the very people who lose their homes, farms and livelihoods when river valleys are flooded by dams.

Even before a dam has produced a single watt of power, or litre of irrigation water, tens of thousands of people may need to be evacuated from the river valleys to make way for the reservoir. World-wide, the flooded valleys that accompany large dams have forced at least 30 million people to abandon their homes since the 1930s, according to IRN. In the past, governments have seen the human cost of displacement as an inevitable "side effect" of development. Now these displaced people are fighting to be heard.

"Past experiences," says one report to the Commission, "show that typical resettlement programmes are: often prepared late in the project cycle; under financed; devised using insufficient understanding of people's social, cultural, economic, psychological conditions and environment in which they were located; implemented with a very short time frame, with limited objective of restoring previous income levels, and too often terminated even before all displaced people were resettled and rehabilitated."...

Some of those opposed to large-scale dam construction ... see the development that dams supposedly promote as spurious in any case, even for the largely urban communities who benefit. ...

Other critics suggest that the dam industry simply turned to developing countries because the market in developed countries had almost dried up. In the past, loans from the World Bank and international aid programmes indirectly kept the multi-billion dollar industry afloat, while scoring lucrative trade and technology transfer deals for the lending nations. But now, under mounting opposition from pressure groups, the U.S. and many European governments have declined to become involved in projects like the Three Gorges and Narmada dams.

With power still mainly in the hands of the dam builders, the coming WCD report might at least provide guidelines on how to include the dispossessed among those who benefit, while minimizing the extent of irreversible damage.

\section{New Dams are Threatening the World's Largest Rivers World Wildife Fund http://www.wwf.org.au/news/n84/}

A WWF report warns that indiscriminate dam-building is threatening the world's largest and most important rivers, with the Yangtze in China, the La Plata in South America, and the Tigris and Euphrates in the Middle East likely to suffer most from dams.

The WWF report, Rivers at Risk, identifies the top 21 rivers at risk from dams being planned or under construction. It shows that over $60 \%$ of the world's 227 largest rivers have been fragmented by dams, which has led to the destruction of wetlands, a decline in freshwater species - including river dolphins, fish, and birds - and the forced displacement of tens of millions of people.

The report highlights the Yangtze as the river at most risk with 46 large dams planned or under construction. The Danube and Amazon rivers are also included in the list. The World Commission on Dams provided recommendations and guidelines that allow us to do just that. However, the report concludes that governments are not applying these recommendations to their dam projects. As a result, the benefits that dams provide - such as hydropower, irrigation, and flood control services - are often overtaken by negative environmental and social impacts. For example, much of 
the water provided by dams is lost, mainly due to inefficient agriculture irrigation systems - which globally waste up to 1,500 trillion litres of water annually. This is equivalent to 10 times the annual water consumption of the entire African continent.

According to the report, downstream communities suffer most from dams, with rivers running dry and fish stocks decimated. Dams disrupt the ecological balance of rivers by depleting them of oxygen and nutrients, and affecting the migration and reproduction of fish and other freshwater species. For example, China - the country with the most number of dams planned or under construction in the world - may lose endangered species such as the Yangtze River Dolphin and many water birds if indiscriminate dam-building continues to destroy their habitats.

\section{More damage than benefits}

... When a dam is constructed, the scars on the landscape are highly visible and when the reservoir starts filling up the damage to the inundated land, sometimes farmlands, sometimes pristine ecosystems, is obvious. But the environmental impacts of a dam stretch much further than the location of the actual dam site.

Migratory fish species are particularly vulnerable to dams, which block access to their spawning or feeding sites. Fish ladders have been successful to some extent for species such as salmon, but are not always effective, and are not a viable solution for many tropical rivers. Fish populations are also susceptible to changes in water quality and water temperatures.

Dams change the hydrology of the river and disturb the seasonal fluctuations. This can be particularly damaging in seasonal floodplains, affecting deposits of nutrients as well as the lifecycles of many fish. Dams also change daily flows by releasing water as a reaction to demands for energy, irrigation or even for navigation and recreation.

Water quality can be degraded. Reductions in water quantities can increase salinity and make the water unusable for drinking and for irrigation, as there is no longer enough water travelling downstream to flush the ecosystem. Decomposition of organic matter and the leaching of mercury from the soil can introduce toxins.

The transport of sediment along the river is disrupted. This affects the morphology of the riverbed, downstream flood plains and even coastal deltas, and in turn impacts on ecosystems in these areas. The build up of sedimentation in the reservoir also reduces the capacity of the dam and there is the danger of accumulation of toxic materials.

In tropical areas, the emissions of greenhouse gases from reservoirs pose a serious concern that needs more investigation.

... and a bit of good news

However, dams are not always bad news for all species. Once reservoirs become established they can become important sites for birdlife. Out of 1345 wetlands of international importance under the Ramsar Convention, about 100 are artificial, many of these being water storage areas.

In South Africa in particular, where natural lakes are practically absent, dams have provided habitats for birds such as pelicans, darters and cormorants. Some dam projects have implemented specific habitat restoration measures that can to some extent compensate for the negative impacts of dams

The socio-economic benefits of dams are numerous and in many places dams have undoubtedly contributed to economic development.

Many countries would look different today without hydroelectricity, irrigation, water supplies, flood control, and recreational activities around reservoirs. But the socio-economic 
impacts of dams should be taken into account too. As more and more dams are being built in populated areas of developing countries, the scale of the social and economic effects is growing.

\section{Health}

Dams impact on human health, both positively and negatively. Improved access to clean water is a major benefit of dams. However, the habitat created by dams is also perfect for disease-carriers such as mosquitoes and snails, meaning that diseases such as malaria and schistosomiasis often become endemic in dammed areas. When higher population densities in resettled communities go hand in hand with poor hygiene, tuberculosis, influenza and gastroenteritis are often the result.

\section{Endangered livelihoods}

Finally, the disruption of natural ecosystems, particularly of floodplains, threatens the livelihoods of the millions of people who depend on fisheries, wetlands and regular deposits of sediment for agriculture.

The Narmada Project. Narmada is the fifth largest river in India and largest western-flowing river of the Indian Peninsula. It rises in the Himalayan Maikala ranges in Madhya Pradesh and flows westwards over a length of about $1312 \mathrm{~km}$. before draining into the Gulf of Cambay, $50 \mathrm{~km}$. West of Bharuch City. Part of the river forms the boundary between the States of Madhya Pradesh and Maharasthra and another part forms the boundary between Maharasthra and Gujarat. The last stretch of $161 \mathrm{~km}$. lies in Gujarat. The colonial British government first considered damming the Narmada in the late 19th century. The idea was revived after independence under the thrust of the Nehru's development policy. The Narmada valley project was controversial from its inception and its costs and benefits were disputed by the riparian states i.e. Gujarat, Maharashtra and Madhya Pradesh. In 1969, the Government of India constituted the Narmada Water Disputes Tribunal (NWDT) to resolve the inter-state dispute. A decade later, the Tribunal issued a compromise award which was accepted by the states. By the late 1980s, the Narmada Valley Development Plan (NVDP) envisaged building 30 big dams, 135 medium dams and 3000 small dams on the Narmada and its tributaries. The people of the Narmada valley who would be displaced began organizing in 1985-86. Other major dams in various stages of planning and construction have also been the subject of protests.

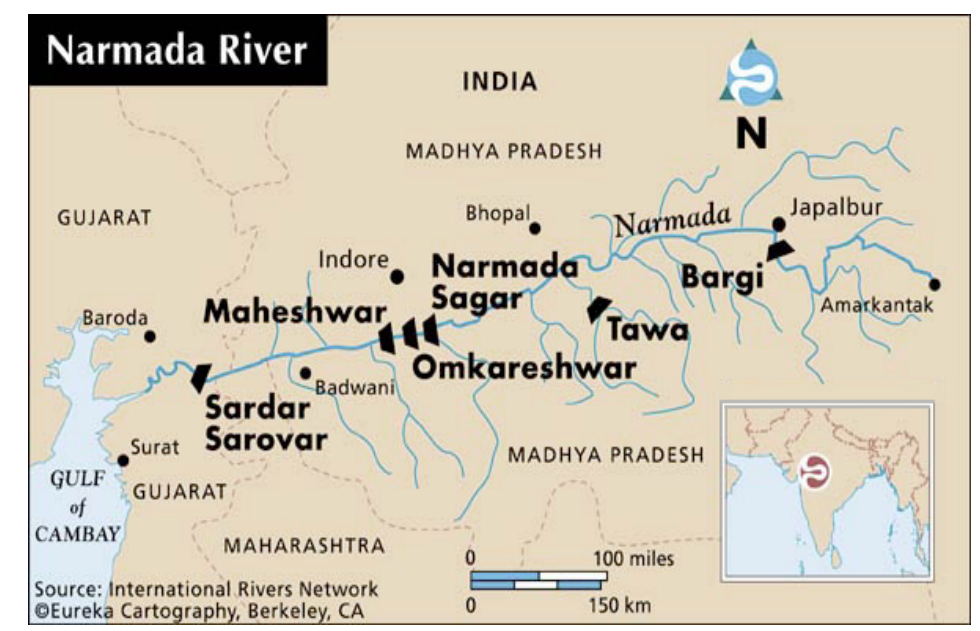




\author{
A Barrage of Protest \\ Peter Coles and Lyla Bavadam, UNESCO Courrier, April 2000
}

.... According to a report by Narmada Bachao Andolan (NBA), a pressure group fighting the Narmada project, when the Bargi dam was finished in 1990, over 1,000 km upstream in Madhya Pradesh, the 114,000 people from 162 villages in the path of the floodwaters were simply jettisoned with nowhere to go. The government, says NBA, offered no resettlement land and only minimal cash compensation. Many of these villagers, says the report, now have menial jobs in the slums of Jabalpur, the main city in the region.

The plight of the Vadaj oustees could be shared by over 300,000 others as construction moves slowly ahead on the 30 large dams, 150 medium and 3,000 smaller dams in a vast project that will transform the Narmada into a staircase of reservoirs and turbines. For the past 15 years, the backlash of opposition from NBA, a coalition of local people's movements opposed to the different dams, has been challenging the view of development that these dams promote. NBA argues that the beneficiaries of the project will be city dwellers, not the rural communities forced to leave their homes in the flooded valley.

Over 80 per cent of India's rural households have no electricity-and little hope of ever being connected to the electricity grid-according to Arundhati Roy, the acclaimed Indian author who has recently championed NBA's struggle. She says the increased food that the dams' irrigation canals may produce will be destined for export, doing little to feed the nation's poor. In 1995, she says, some 30 million tons of unsold grain were stockpiled in state granaries, while 350 million Indians still live below the poverty line. What is more, most of the people affected by the Narmada project, says NBA, are tribal communities, fishing villages and Dalits (the so-called "oppressed" lower stratum of the Hindu caste system), who already benefit least from India's prosperity.

The notion of dam building as a prime technology solution to development is not new. Back in the 1940s, just after Independence, Prime Minister Jawaharlal Nehru saw dams as "the Temples of Modern India". The Narmada Valley Development Project was to be a showcase for this vision. Although this particular project stayed on the drawing board for over 30 years, mostly because of disputes over water rights between the three states-Madhya Pradesh, Maharashtra and Gujaratthrough which the Narmada flows, India went on to build some 3,600 dams.

Coupled to the Green Revolution of the 1960s, these dams provided massive irrigation systems that have underpinned a fourfold increase in food production. And similar prospects are being heralded for the Narmada dams. According to official figures, the Sardar Sarovar dam, the last and largest of the dams before the river reaches the Arabian Sea, will provide water for 20-30 million people all year round, especially in the arid areas of Kutch, Saurashtra and the state of Rajasthan. At the same time, the 138.6-metre multi-purpose dam is scheduled to produce 1,450 MW of hydroelectric power, while its reservoir should smooth out the yearly seesaw of floods and droughts, protecting some 400,000 people.

\title{
World Bank withdrawal
}

NBA contests just about all the official statistics on the future benefits of the project. It also questions the very principle of the dams from the point of view of development. Led by Medha Patkar, a sociologist originally from Bombay, NBA argues that the benefits will never justify the irreversible loss of forest, fisheries, farmland, culture and livelihood for the hundreds of thousands of displaced people. Some 30 million people depend directly or indirectly on the 1,312-km-long river and its valley, with its fertile farmland, historic temples and pilgrimage routes.

In 1986, a year after the World Bank lent $\$ 450$ million to construct Sardar Sarovar, NBA commissioned a series of impact assessment studies that, it claims, exposed crucial flaws in the official cost-benefit analyses for the entire project. But at the heart of NBA's campaign is the apparent lack of resettlement provision for oustees. With mounting international support, NBA was able to force a review of the Narmada project. In 1991 the World Bank commissioned an independent inquiry, 
whose report essentially endorsed the NBA claims, saying that there had been "no proper appraisal" of the project's impact. Two years later, in an unprecedented about-turn, the World Bank withdrew from the scheme.

In 1994, India's Supreme Court upheld a case presented by NBA, freezing all construction on the Narmada dams until the state governments carried out adequate impact assessments. NBA insists that there must be no displacement if there are no realistic plans for resettlement. With the exception of Sardar Sarovar, none of the dam projects had any resettlement plans, says the organization. NBA is adamant that it is not opposed to the development that the dams promise. It is also looking for a compromise solution, calling for the final height of the dams to be reduced. The lower the final height, the fewer people will be forced to move to make way for the reservoirs and the less land will be lost.

\section{Rally in the valley}

Although it now seems unlikely that NBA's actions will stop the dams, the organization has brought the issue of resettlement to the fore. In 1998 the Madhya Pradesh government set up a task force to look at resettlement possibilities. It found that not only was there no land in Madhya Pradesh to house oustees but that the land promised by Gujarat either did not exist, or was of too poor quality. Madhya Pradesh has now called for a new evaluation. The state of Gujarat, however, has dug in its heels. Not only did it refuse to allow the independent World Commission on Dams, set up by the World Bank to visit the Sardar Sarovar site, it also challenged the Supreme Court's earlier ruling. In February 1999, after a four-year moratorium, the Supreme Court reversed its earlier decision, allowing construction to begin again at Sardar Sarovar, adding a further 5 metres to the 80 metres already built.

NBA has now reinforced its struggle, organizing a series of passive sit-ins and hunger strikes. At the end of July last year Arundhati Roy organized a "Rally in the Valley", marching with 400 other public figures and supporters from village to village in the affected area. An estimated 10,000 oustees joined the rally in the fertile Nimad region of Madhya Pradesh, where the local farmers will lose their land if construction goes ahead. And when the monsoon rains began in August 1999, Medha Patkar and other NBA members took up positions in the village of Domkhedi, refusing to move as the flood waters rose up to their shoulders. Police in boats finally removed them. At the end of last year, Arundhati Roy published a closely-documented essay entitled "The Greater Common Good" in Outlook magazine, criticizing the Narmada Valley project both in principle and in its application.

As the mud flies between NBA and supporters of the project, the withdrawal of the World Bank could have unpredictable effects in the longer term. With most international aid programmes now unwilling to be associated with the dams, the developers are looking for private sector funding. This could be much harder to influence than an institution such as the World Bank, which has a "worthy" image to protect.

\section{The realities of resettlement}

In some cases resettlement has meant the fragmentation of village communities, because neighbours are given land in different sites. Meanwhile, over 5,000 oustees from villages in Gujarat are being rehoused in settlements alongside others from Maharashtra and Madhya Pradesh. People from three different states, each with their own languages and dialects, culinary habits and dress, are thrown together.

Resettled people may also have to face hostility from their host communities. New lands can be barren rocky ground or waterlogged, saline stretches where farming is impossible. Fishing communities find themselves far from the river on which their livelihood has depended for centuries. Often, these resettled people try to return to their original homes, even if all that remains is a muddy hilltop.

Uncertainty is another dimension of resettlement. Entire generations grow up not knowing what the ultimate fate of their village will be. As NBA activist Shripad Dharmadhikari explains, "when it is announced that an area will face submergence, all development work comes to a halt. So if a school is being built or roads are being constructed it is all stopped. The actual submergence may 
remain on paper but the work stops." In the village of Kakarana Behena, a Bhillala tribesman said the electric supply to his village was cut when its status as a submergence village became known. Power supply was stopped a year ago but the waters are still below Kakarana.

There are also social ramifications. Sulgaon is a village in the prosperous and fertile Nimad region that will be submerged when the Maheshwar dam in Madhya Pradesh is constructed. Lakshman Patidar says it is becoming increasingly difficult to find brides for eligible boys. "Who will want to send their daughters to a home that will soon be under water?" he asks. And, like other Nimadi farmers, Patidar values his land above all else. Since boys invariably join their fathers on the farm they get little formal education. This will make it even harder to adapt to their loss of livelihood and culture.

\section{NARMANA BACHAO ANDOLAN V. UNION OF INDIA AND OTHERS} [2000] INSC 518 (18 October 2000)

KIRPAL,J.

$$
\cdots
$$

The Narmada Bachao Andolan, the petitioner herein, had been in the forefront of agitation against the construction of the Sardar Sarovar Dam.

In April, 1994 the petitioner filed the present writ petition inter alia praying that the Union of India and other respondents should be restrained from proceeding with the construction of the dam. . .

On behalf of the petitioners, the arguments of Sh. Shanti Bhushan, learned senior counsel, were divided into four different heads, namely, general issues, issues regarding environment, issues regarding relief and rehabilitation and issues regarding review of Tribunals Award. The petitioners have sought to contend that it is necessary for some independent judicial authority to review the entire project, examine the current best estimates of all costs (social, environmental, financial), benefits and alternatives in order to determine whether the project is required in its present form in the national interest or whether it needs to be re- structured/modified. It is further the case of the petitioners that no work should proceed till environment impact assessment has been fully done and its implications for the projects viability being assessed in a transparent and participatory manner. This can best be done, it is submitted, as a part of the comprehensive review of the project.

While the State of Madhya Pradesh has partly supported the petitioners inasmuch as it has also pleaded for reduction in the height of the dam so as to reduce the extent of submergence and the consequent displacement, the other States and the Union of India have refuted the contentions of the petitioners and of the State of Madhya Pradesh. While accepting that initially the relief and rehabilitation measures had lagged behind but now adequate steps have been taken to ensure proper implementation of relief and rehabilitation at least as per the Award. The respondents have, while refuting other allegations, also questioned the bona fides of the petitioners in filing this petition. It is contended that the cause of the tribals and environment is being taken up by the petitioners not with a view to benefit the tribals but the real reason for filing this petition is to see that a high dam is not erected per se. It was also submitted that at this late stage this Court should not adjudicate on the various issues raised specially those which have been decided by the Tribunals Award.

\section{GENERAL ISSUSES RELATING TO DISPLACEMENT OF TRIBALS AND ALLEGED VIOLATION OF THE RIGHTS UNDER ARTICLE 21 OF THE CONSTITUION}

The submission of Sh. Shanti Bhushan, learned senior counsel for the petitioners was that the forcible displacement of tribals and other marginal farmers from their land and other sources of livelihood for a project which was not in the national or public interest was a violation of their fundamental rights under Article 21 of the Constitution of India read with ILO Convention 107 to which India is a signatory. Elaborating this contention, it was submitted that this Court had held in a 
large number of cases that international treaties and covenants could be read into the domestic law of the country and could be used by the courts to elucidate the interpretation of fundamental rights guaranteed by the Constitution. Reliance in support of was drawn to the ILO Convention 107 which stipulated that tribal populations shall not be removed from their lands without their free consent from their habitual territories except in accordance with national laws and regulations for reasons relating to national security or in the interest of national economic development. It was further stated that the said Convention provided that in such cases where removal of this population is necessary as an exceptional measure, they shall be provided with lands of quality at least equal to that of lands previously occupied by them, suitable to provide for their present needs and future development. Sh. Shanti Bhushan further contended that while Sardar Sarovar Project will displace and have an impact on thousands of tribal families it had not been proven that this displacement was required as an exceptional measure. He further submitted that given the seriously flawed assumptions of the project and the serious problems with the rehabilitation and environmental mitigation, it could not be said that the project was in the best national interest. It was also submitted that the question arose whether the Sardar Sarovar project could be said to be in the national and public interest in view of its current best estimates of cost, benefits and evaluation of alternatives and specially in view of the large displacement of tribals and other marginal farmers involved in the project. Elaborating this contention, it was contended that serious doubts had been raised about the benefits of the project - the very rationale which was sought to justify the huge displacement and the massive environmental impacts etc. It was contended on behalf of the petitioners that a project which was sought to be justified on the grounds of providing a permanent solution to water problems of the drought prone areas of Gujarat would touch only the fringes of these areas, namely, Saurashtra and Kutch and even this water, which was allocated on paper, would not really accrue due to host of reasons. It was contended that inspite of concentrating on small scale decentralized measures which were undertaken on a large scale could address the water problem of these drought prone areas. Huge portions of the State resources were being diverted to the Sardar Sarovar Project and as a result the small projects were ignored and the water problem in these areas persists. It was submitted that the Sardar Sarovar Project could be restructured to minimise the displacement.

\section{ENVIRONMENTAL ISSUES}

The four issues raised under this head by Sh. Shanti Bhushan are as under:

I. Whether the execution of a large project, having diverse and far reaching environmental impact, without the proper study and understanding of its environmental impact and without proper planning of mitigative measures is a violation of fundamental rights of the affected people guaranteed under Article 21 of the Constitution of India?

II. Whether the diverse environmental impacts of the Sardar Sarovar Project have been properly studied and understood?

III. Whether any independent authority has examined the environmental costs and mitigative measures to be undertaken in order to decide whether the environmental costs are acceptable and mitigative measures practical?

IV. Whether the environmental conditions imposed by the Ministry of Environment have been violated and if so, what is the legal effect of the violations?

It was submitted by Sh. Shanti Bhushan that a large project having diverse and far reaching environmental impacts in the concerned States would require a proper study and understanding of the environmental impacts. He contended that the study and planning with regard to environmental impacts must precede construction. According to Sh. Shanti Bhushan, when the environmental clearance was given in 1987, proper study and analysis of the environmental impacts and mitigative measures, which were required to be taken, were not available and, therefore, this clearance was not valid. The decision to construct the dam was stated to be political one and was not a considered 
decision after taking into account the environmental impacts of the project. The execution of SSP without a comprehensive assessment and evaluation of its environmental impacts and a decision regarding its acceptability was alleged to be a violation of the rights of the affected people under Article 21 of the Constitution of India. It was further submitted that no independent authority has examined vehemently the environmental costs and mitigative measurers to be undertaken in order to decide whether the environmental costs are acceptable and mitigative measures practical. With regard to the environmental clearance given in June, 1987, the submission of Sh. Shanti Bhushan was that this was the conditional clearance and the conditions imposed by the Ministry of Environment and Forests had been violated.

The letter granting clearance, it was submitted, disclosed that even the basic minimum studies and plans required for the environmental impact assessment had not been done. Further more it was contended that in the year 1990, as the deadline for completion of the studies was not met, the Ministry of Environment and Forests had declared that the clearance had lapsed. The Secretary of the said Ministry had requested the Ministry of Water Resources to seek extension of the clearance but ultimately no extension was sought or given and the studies and action plans continued to lag to the extent that there was no comprehensive environmental impact assessment of the project, proper mitigation plans were absent and the costs of the environmental measures were neither fully assessed nor included in the project costs. In support of his contentions, Sh. Shanti Bhushan relied upon the report of a Commission called the Independent Review or the Morse Commission. The said Commission had been set up by the World Bank and it submitted its report in June, 1992. In its report, the Commission had adversely commented on practically all aspects of the project and in relation to environment, it was stated as under:

Important assumptions upon which the projects are based are now questionable or are known to be unfounded.

Environmental and social trade-off have been made, and continue to be made, without a full understanding of the consequences. As a result, benefits tend to be over-stated, while social and environmental costs are frequently understated. Assertions have been substituted for analysis.

We think that the Sardar Sarovar Projects as they stand are flawed, that resettlement and rehabilitation of all those displaced by the projects is not possible under the prevailing circumstances, and that the environmental impacts of the projects have not been properly considered or adequately addressed.

The history of environmental aspects of Sardar Sarovar is a history of non-compliance. There is no comprehensive impact statement. The nature and magnitude of environmental problems and solutions remain elusive.

Sh. Shanti Bhushan submitted that it had become necessary for some independent judicial authority to review the entire project, examine the current best estimates of all costs (social, environmental, financial), benefits and alternatives in order to determine whether the project is required in its present form in the national interest, or whether it needs to be restructured/modified.

Sh. Shanti Bhushan further submitted that environmental impacts of the projects were going to be massive and full assessment of these impacts had not been done. According to him the latest available studies show that studies and action plans had not been completed and even now they were lagging behind pari passu. It was also contended that mere listing of the studies does not imply that everything is taken care of. Some of the studies were of poor quality and based on improper data and no independent body had subjected these to critical evaluation.

\section{RE: ENVIRONMENTAL CLERANCE}

$$
\cdots
$$

From the documents and the letters referred to hereinabove, it is more than evident that the Government of India was deeply concerned with the environmental aspects of the Narmada Sagar and 
Sardar Sarovar Project. Inasmuch as there was some difference of opinion between the Ministries of Water Resources and Environment \& Forests with regard to the grant of environmental clearance, the matter was referred to the Prime Minister. Thereafter, series of discussions took place in the Prime Ministers Secretariat and the concern of the Prime Minister with regard to the environment and desire to safeguard the interest of the tribals resulted in some time being taken. The Prime Minister gave environmental clearance on 13th April, 1987 and formal letter was issued thereafter on 24th June, 1987.

It is not possible, in view of the aforesaid state of affairs, for this Court to accept the contention of the petitioner that the environmental clearance of the project was given without application of mind. It is evident, and in fact this was the grievance made by Shri Vaghela, that the environmental clearance of the project was unduly delayed. The Government was aware of the fact that number of studies and data had to be collected relating to environment. Keeping this in mind, a conscious decision was taken to grant environmental clearance and in order to ensure that environmental management plans are implemented pari passu with engineering and other works, the Narmada Management Authority was directed to be constituted. This is also reflected from the letter dated 24th June, 1987 of Shri Mudgal giving formal clearance to the project.

It was submitted by Sh. Shanti Bhushan that the catchment area treatment programme was not to be done pari passu but was required to be completed before the impoundment. This contention was based on the terms of the letter dated 24th June, 1987 wherein conditional environmental clearance was granted, inter alia, on the condition that the catchment area treatment programme and rehabilitation plans be drawn so as to be completed ahead of reservoir filling. Admittedly, the impounding began in 1994 and the submission of Sh. Shanti Bhushan was that catchment area treatment programme had not been completed by them and, therefore, this very important condition had been grossly violated. Reference was also made to the Minutes of the Environmental Sub-group meetings to show that there had been slippage in catchment area treatment work.

The clearance of June, 1987 required the work to be done pari passu with the construction of the dams and the filling of the reservoir. The area wherein the rainfall water is collected and drained into the river or reservoir is called catchment area and the catchment area treatment was essentially aimed at checking of soil erosion and minimising the silting in the reservoir within the immediate vicinity of the reservoir in the catchment area. The respondents had proceeded on the basis that the requirement in the letter of June, 1987 that catchment area treatment programme and rehabilitation plans be drawn up and completed ahead of reservoir filling would imply that the work was to be done pari passu, as far as catchment area treatment programme is concerned, with the filling of reservoir. Even though the filling of the reservoir started in 1994, the impoundment Award was much less than the catchment area treatment which had been affected. The status of compliance with respect to pari passu conditions indicated that in the year 1999, the reservoir level was 88.0 meter, the impoundment area was 6881 hectares $(19 \%)$ and the area where catchment treatment had been carried out was 128230 hectares being $71.56 \%$ of the total work required to be done. The Minutes of the Environmental Sub-group as on 28th September, 1999 stated that catchment area treatment works were nearing completion in the states of Gujarat and Maharashtra. Though, there was some slippage in Madhya Pradesh, however, overall works by and large were on schedule. This clearly showed that the monitoring of the catchment treatment plan was being done by the Environmental Sub-group quite effectively.

With regard to compensatory afforestation it was contended by Sh. Shanti Bhushan that it was being carried out outside the project impact area. Further, it was submitted that the practice of using waste land or lesser quality land for compensatory afforestation means that the forest will be of lesser quality. Both of these together defeated the spirit of the compensatory afforestation. It was contended that the whole compensatory afforestation programme was needed to be looked at by independent experts.

While granting approval in 1987 to the submergence of forest land and/or diversion thereof for the SSP, the Ministry of Environment and Forests had laid down a condition that for every hectare of forest land submerged or diverted for construction of the project, there should be compensatory 
afforestation on one hectare of non-forest land plus reforestation on two hectare of degraded forest. According to the State of Gujarat, it had fully complied with the condition by raising afforestation in 4650 hectares of non-forest areas and 9300 hectares in degraded forest areas before 1995-96 against the impoundment area of $19 \%$. The pari passu achievement of afforestation in Gujarat was stated to be $99.62 \%$. If afforestation was taking place on waste land or lesser quality land, it did not necessarily follow, as was contended by the petitioners, that the forests would be of lesser quality or quantity.

It was also contended on behalf of the petitioners that downstream impacts of the project would include not only destruction of downstream fisheries, one of the most important ones in Gujarat on which thousands of people are dependent but will also result in salt water ingress. The project, it was contended, will have grave impacts on the Narmada Estuary and unless the possible impacts were properly studied and made public and mitigation plans demonstrated with the requisite budget, one could not accept the claim that these matters were being looked into. The need to assess the problem was stated to be urgent as according to the petitioners rich fisheries downstream of the dam, including the famed Hilsa would be almost completely destroyed. The salinity ingress threatened the water supply and irrigation use of over 210 villages and towns and Bharuch city.

All these would not only have serious economic and other impacts but would also directly destroy the livelihoods of at least 10000 fisher families.

... [A]ccording to the respondents, in 1992 Sardar Sarovar Narmada Nigam Limited issued an approach paper on environmental impact assessment for the river reach downstream. This provided technical understanding of the likely hydrological changes and possible impact in relation thereto. It was further submitted by learned counsel for the respondents that the potential for environmental changes in the lower river and estuary had to be seen in the context of the long term development of the basin. The current stage was clearly beneficial. ...

The ... report [in evidence] clearly demonstrates that the construction of dam would result into more regulated and perennial flow into the river with an overall beneficial impact. It is also evident that until all the dams are constructed upstream and the entire flow of river is harnessed, which is not likely in the foreseeable future, there is no question of adverse impact including the fishing activity and the petitioners assertions in this regard are ill-conceived.

The area of submergence was stated to be rich in archaeological remains but it still remained to be studied. It was contended that there was danger of rich historical legacy being lost and even a small increase in the dam height would threaten to submerge many of the sites listed in the report of the Archaeological Survey of India. There were stated to be five monuments which would be affected at the dam height of 90 meter or above and no work was stated to have commenced to protect any of the five monuments.

In the case of Sardar Sarovar, where several sites may be submerged, the NDWT award stipulated that the entire cost of relocation and protection should be chargeable to Gujarat. Relocation work was to be supervised by the Department of Archaeology under the provisions of the Ancient Monuments and Archaeological Sites and Remains Act, 1958.

The three State Governments carried out a complete survey of cultural and religious sites within the submergence zone. The principle of these surveys was to list all Archaeological sites, identify and name any site under state protection and further identify sites of religious or cultural significance which, although not protected under national law, were of sufficient value to merit relocation. So far as the State of Gujarat is concerned the Department of Archaeology surveyed archeological sites in nineteen villages of submergence zone in Gujarat under the title of Archaeological Survey of Nineteen Villages in Gujarat submerged by Sardar Sarovar Reservoir, 1989. $\ldots$

In relation to flora and fauna studies, it was contended by the petitioners that the studies had finished only recently and the action plans were awaited in many cases. In the meanwhile, extensive deforestation of the submergence zone had taken place, as also part of the area had been submerged, even as the studies have been on. It was also contended that the impact on some of these Wild Ass Sanctuary in Kutch would be very severe. 
... When there is a state of uncertainty due to lack of data or material about the extent of damage or pollution likely to be caused then, in order to maintain the ecology balance, the burden of proof that the said balance will be maintained must necessarily be on the industry or the unit which is likely to cause pollution. On the other hand where the effect on ecology or environment of setting up of an industry is known, what has to be seen is that if the environment is likely to suffer, then what mitigative steps can be taken to off set the same. Merely because there will be a change is no reason to presume that there will be ecological disaster. It is when the effect of the project is known then the principle of sustainable development would come into play which will ensure that mitigative steps are and can be taken to preserve the ecological balance. Sustainable development means what type or extent of development can take place which can be sustained by nature/ecology with or without mitigation.

In the present case we are not concerned with the polluting industry which is being established. What is being constructed is a large dam. The dam is neither a nuclear establishment nor a polluting industry. The construction of a dam undoubtedly would result in the change of environment but it will not be correct to presume that the construction of a large dam like the Sardar Sarovar will result in ecological disaster. India has an experience of over 40 years in the construction of dams. The experience does not show that construction of a large dam is not cost effective or leads to ecological or environmental degradation. On the contrary there has been ecological upgradation with the construction of large dams. What is the impact on environment with the construction of a dam is wellknown in India and, therefore, the decision in A.P. Pollution Control Boards case (supra) will have no application in the present case. ....

In India notification had been issued under Section 3 of the Environmental Act regarding prior environmental clearance in the case of undertaking of projects and setting up of industries including Inter-State River Project. This notification has been made effective from 1994. There was, at the time when the environmental clearance was granted in 1987, no obligation to obtain any statutory clearance. The environmental clearance which was granted in 1987 was essentially administrative in nature, having regard and concern of the environment in the region. Change in environment does not per se violate any right under Article 21 of the Constitution of India especially when ameliorative steps are taken not only to preserve but to improve ecology and environment and in case of displacement, prior relief and rehabilitation measures take place pari passu with the construction of the dam.

At the time when the environmental clearance was granted by the Prime Minister whatever studies were available were taken into consideration. It was known that the construction of the dam would result in submergence and the consequent effect which the reservoir will have on the ecology of the surrounding areas was also known. Various studies relating to environmental impact, some of which have been referred to earlier in this judgment, had been carried out. There are different facets of environment and if in respect of a few of them adequate data was not available it does not mean that the decision taken to grant environmental clearance was in any way vitiated. The clearance required further studies to be undertaken and we are satisfied that this has been and is being done. Care for environment is an on going process and the system in place would ensure that ameliorative steps are taken to counter the adverse effect, if any, on the environment with the construction of the dam.

\section{RELIEF AND REHABILITATION}

It is contended by the petitioner that as a result of construction of dam over 41,000 families will be affected in three States spread over 245 villages. The number of families have increased from 7000 families assessed by the Tribunal. It was further contended that the submergence area can be broadly divided into two areas, fully tribal area which covers the initial reach of about 100 or so villages which are almost $100 \%$ tribal and hilly. These include all the 33 villages of Maharashtra, all 19 of Gujarat and many of the Madhya Pradesh. The second part of the submergence area is the mixed population area on the Nimad plains with a very well developed economy that is well connected to the mainstream. While the tribal areas are stated to be having a rich and diverse resource base and the self 
sufficient economy, the lack of so-called modern amenities like roads, hospitals and schools are far more a reflection of the neglect and disregard by the Government over the last fifty years than on anything else. Of the 193 villages stated to be affected by Sardar Savorar submergence 140 lie in the Nimad plains. The population of these villages are a mixture of caste and tribal and these villages have all the facilities like schools, post offices, bus service etc. . . .

In order to consider the challenge to the execution of the project with reference to Relief and Rehabilitation it is essential to see as to what is the extent and the nature of submergence.

The Sardar Sarovar Reservoir level at $455 \mathrm{ft}$. would affect 193 villages in Madhya Pradesh, 33 villages in Maharashtra and 19 villages in Gujarat. The submergence villages are situated on the banks of river Narmada having gentle to steep slopes of the Satpura hills. A village is considered affected even when the water level touches the farm/hut at lowest level. It may be noted that only 4 villages ( 3 villages in Gujarat and 1 village in Madhya Pradesh) are getting submerged fully and the rest 241 villages are getting affected partially.

The tribals who are affected are in indigent circumstances and who have been deprived of modern fruits of development such as tap water, education, road, electricity, convenient medical facilities etc. The majority of the project affected families are involved in rain-fed agricultural activities for their own sustenance. There is partial employment in forestry sector.

Since the area is hilly with difficult terrain, they are wholly dependent on vagaries of monsoon and normally only a single crop is raised by them. Out of the PAFs of Madhya Pradesh who have resettled in Gujarat, more than $70 \%$ are tribal families. Majority of the total tribal PAFs are stated to have already been re-settled in Gujarat after having exercised their option. It is the contention of the State of Gujarat that the tribals in large number have responded positively to the re-settlement package offered by that state.

In Madhya Pradesh, the agricultural lands of the tribal villages are affected on an average to the extent of $28 \%$ whereas in the upper reaches i.e. Nimad where the agriculture is advanced, the extent of submergence, on an average, is only $8.5 \%$. The surveys conducted by HMS Gour University (Sagar) the Monitoring and Evaluation Agency, set up by Government of Madhya Pradesh, reveals that the major resistance to relocation is from the richer, non-tribal families of Nimad who fear shortage of agricultural labour if the landless labourers from the areas accept re- settlement.

The displacement of the people due to major river valley projects has occurred in both developed and developing countries. In the past, there was no definite policy for rehabilitation of displaced persons associated with the river valley projects in India. There were certain project specific programmes for implementation on temporary basis. For the land acquired, compensation under the provisions of Land Acquisition Act, 1894 used to be given to the project affected families. This payment in cash did not result in satisfactory resettlement of the displaced families. Realising the difficulties of displaced persons, the requirement of relief and rehabilitation of PAFs in the case of Sardar Sarovr Project was considered by the Narmada Water Disputes Tribunal and the decision and final order of the Tribunal given in 1979 contains detailed directions in regard to acquisition of land and properties, provision for land, house plots and civic amenities for the re- settlement and rehabilitation of the affected families. The re-settlement policy has thus emerged and developed along with Sardar Sarovar Project.

The Award provides that every displaced family, whose more than $25 \%$ of agricultural land holding is acquired, shall be entitled to and be allotted irrigable land of its choice to the extent of land acquired subject to the prescribed ceiling of the State concerned with a minimum of two hectares land. Apart from this land based rehabilitation policy, the Award further provides that each project affected persons will be allotted a house plot free of cost and re-settlement and rehabilitation grant. The civic amenities required by the Award to be provided at places of re-settlement include one primary school for every 100 families, one Panchayat Ghar, one dispensary, one seed store, one childrens park, one village pond and one religious place of worship for every 500 families, one drinking water well with trough and one tree platform for very 50 families; approach road linking each colony to main road; electrification; water supply, sanitary arrangement etc. The State Governments have liberalised the policies with regard to re-settlement and have offered packages more than what was provided for in 
the Award e.g the Governments of Madhya Pradesh, Maharashtra and Gujarat have extended the R\&R benefits through their liberalised policies even to the encroachers, landless/displaced persons, joint holders, Tapu land (Island) holders and major sons (18 years old) of all categories of affected persons. The Government of Maharasthra has decided to allot one hectare of agricultural land free of cost even to unmarried major daughters of all categories of PAFs.

In the environmental clearance granted by the Ministry of Environment and Forests vide its letter dated 24th June, 1987, one of the conditions stipulated therein was for information from the project authorities on various action plans including Rehabilitation Master Plan of 1989. It is the contention of the petitioners that the failure to prepare a Master Plan constitutes non-compliance with the requirement of the Tribunals Award as well as environmental clearance.

The measures which have been implemented for sustainable development with regard to preserving the socio-cultural environment of the displaced persons in the States of Maharashtra, Gujarat and Madhya Pradesh are stated to be as follows:

- Three choices to the people for the selection of relocation sites.

- Integration of the displaced person with the neighbouring villages by organising medical check-up camps, animal husbandry camps, festivals, eye camps, rural development seminar for village workers etc.

- Establishment of rehabilitation committees at different levels.

- Respect of traditional beliefs, rituals and rights at the starting of house construction, the day and time of leaving the old house and village and the day and time of occupying the new house etc.

- The sacred places at the native villages are being recreated along with their settlements at new sites.

- Installation of all the religious deities with the due consultation of religious heads.

- Promotion of cultural milieu viz. Social festivals, religious rights, rights of passage, presence of priests, shaman, kinsmen, clansmen etc.

- Special consideration for the preservation of holistic nature of the culture.

- Proper use of built-in-mechanism of cultural heritage of the displaced persons.

- Launching of culturally appropriate development plan.

- Genuine representation of the traditional leader.

The Tribunal had already made provision of various civic amenities which were further liberalised by the State Governments during implementation. The existing development programmes were strengthened for ensuring sustainable development at the rehabilitation sites. These were Integrated Rural Development Programme (IRDP) for agriculture, business and village industries; Integrated Child Development Scheme (ICDS) for nutrition, health and education; Jawahar Rojgar Yojna (JRY); aids for improved seeds, fertilizers, irrigation, animal husbandry; Training Rural Youth for selfemployment (TRYSEM); Employment Guarantee Scheme (EGS), Social Assistance; Industrial Training Institute (ITI); Tribal Development Programme (TDP), financial benefits to the backward classes, economically weaker sections, tribals and other backward classes (OBC), eye camps, subsidies to farmers (seed, tractorisation, fertilizsers, diesel, etc.) agricultural prices support subsidy etc.

Other benefits which were extended for improving the quality of life of the re-settled PAFs included fodder farm, mobile sale, shop of fodder, seeds cultivation training, initial help in land preparation for agricultural activities, better seeds and fertilizers, access to finance, special programme for women in the traditional skills enterpreneurship development, employment skill formation, different plantation programmes, special emphasis for pasture management, environment awareness and education programme, programmes for bio-gas/smokeless chulhas, safe drinking water supply, electricity, lift irrigation, fertilizers kit distribution, gypsum treatment of soil etc.

The project authorities in these three States of Madhya Pradesh, Gujarat and Maharashtra represented that comprehensive health care was available in tribal areas where the displaced families 
had been re-settled. It was contended that extensive preventive health measures like mass immunization, anti-malaria programme, family welfare programmes, child development schemes etc. had been undertaken. What is important is that primary health centres were established at relocation sites for all necessary health facilities to the PAFs.

Re-settlement and rehabilitation packages in the three States were different due to different geographical, local and economic conditions and availability of land in the States. The liberal packages available to the Sardar Sarovar Project oustees in Gujarat are not even available to the project affected people of other projects in Gujarat. It is incorrect to say that the difference in $R \& R$ packages, the package of Gujarat being the most liberal, amounts to restricting the choice of the oustees. Each State has its own package and the oustees have an option to select the one which was most attractive to them. A project affected family may, for instance, chose to leave its home State of Madhya Pradesh in order to avail the benefits of more generous package of the State of Gujarat while other PAFs similarly situated may opt to remain at home and take advantage of the less liberal package of the State of Madhya Pradesh. There is no requirement that the liberalisation of the packages by three States should be to the same extent and at the same time, the States cannot be faulted if the package which is offered, though not identical with each other, is more liberal than the one envisaged in the Tribunals Award.

Subsequent to the Tribunals Award, on the recommendation of the World Bank, the Government of Gujarat adopted the principle of re- settlement that the oustees shall be relocated as village units, village sections or families in accordance with the outstees preference. The oustees choice has actively guided the re-settlement process. The requirement in the Tribunals Award was that the Gujarat shall establish rehabilitation villages in Gujarat in the irrigation command of the Sardar Sarovar Project on the norms mentioned for rehabilitation of the families who were willing to migrate to Gujarat. This provision could not be interpreted to mean that the oustees families should be resettled as a homogeneous group in a village exclusively set up for each such group.

The concept of community wise re-settlement, therefore, cannot derive support from the above quoted stipulation. Besides, the norms referred to in the stipulation relate to provisions for civic amenities. They vary as regards each civic amenity vis-à-vis the number of oustees families. Thus, one panchayat ghar, one dispensary, one childrens park, one seed store and one village pond is the norm for 500 families, one primary school (3 rooms ) for 100 families and a drinking water well with trough and one platform for every 50 families. The number of families to which the civic amenities were to be provided was thus not uniform and it was not possible to derive therefrom a standardised pattern for the establishment of a site which had nexus with the number of oustees families of a particular community or group to be resettled. These were not indicators envisaging re-settlement of the oustees families on the basis of tribes, sub-tribes, groups or sub-groups.

While re-settlement as a group in accordance with the oustees preference was an important principle/objective, the other objectives were that the oustees should have improved or regained the standard of living that they were enjoying prior to their displacement and they should have been fully integrated in the community in which they were re-settled. These objectives were easily achievable if they were re-settled in the command area where the land was twice as productive as the affected land and where large chunks of land were readily available. This was what the Tribunals Award stipulated and one objective could not be seen in isolation of the other objectives.

The Master Plan, 1995 of Narmada Control Authority also pointed out that "the Bhils, who are individualistic people building their houses away from one another, are getting socialised; they are learning to live together".

Looking to the preferences of the affected people to live as a community, the Government of Gujarat had basically relied on the affected families decision as to where they would like to relocate, instead of forcing them to relocate as per a fixed plan.

The underlined principle in forming the R\&R policy was not merely of providing land for PAFs but there was a conscious effort to improve the living conditions of the PAFs and to bring them into the mainstream. .... 
Dealing with the contention of the petitioners that there is a need for a review of the project and that an independent agency should monitor the R\&R of the oustees and that no construction should be permitted to be undertaken without the clearance of such an authority, the respondents are right in submitting that there is no warrant for such a contention. The Tribunals Award is final and binding on the States. The machinery of Narmada Control Authority has been envisaged and constituted under the Award itself. It is not possible to accept that Narmada Control Authority is not to be regarded as an independent authority. Of course some of the members are Government officials but apart from the Union of India, the other States are also represented in this Authority. The project is being undertaken by the Government and it is for the Governmental authorities to execute the same. With the establishment of the R\&R Sub-group and constitution of the Grievances Redressal Authorities by the States of Gujarat, Maharashtra and Madhya Pradesh, there is a system in force which will ensure satisfactory re-settlement and rehabilitation of the oustees. There is no basis for contending that some outside agency or National Human Rights Commission should see to the compliance of the Tribunal Award.

\section{CONCLUSION}

Water is one element without which life cannot sustain. Therefore, it is to be regarded as one of the primary duties of the Government to ensure availability of water to the people.

There are only three sources of water. They are rainfall, ground water or from river. A river itself gets water either by the melting of the snow or from the rainfall while the ground water is again dependent on the rainfall or from the river. In most parts of India, rainfall takes place during a period of about 3 to 4 months known as the Monsoon Season. Even at the time when the monsoon is regarded as normal, the amount of rainfall varies from region to region. For example, North-Eastern States of India receive much more rainfall than some of other States like Punjab, Haryana or Rajasthan. Dams are constructed not only to provide water whenever required but they also help in flood control by storing extra water. Excess of rainfall causes floods while deficiency thereof results in drought. Studies show that $75 \%$ of the monsoon water drains into the sea after flooding a large land area due to absence of the storage capacity. According to a study conducted by the Central Water Commission in 1998, surface water resources were estimated at $1869 \mathrm{cu} \mathrm{km}$ and rechargeable groundwater resources at $432 \mathrm{cu} \mathrm{km}$. It is believed that only $690 \mathrm{cu} \mathrm{km}$ of surface water resources (out of $1869 \mathrm{cu} \mathrm{km}$ ) can be utilised by storage. At present the storage capacity of all dams in India is 174 $\mathrm{cu} \mathrm{km}$. which is incidentally less than the capacity of Kariba Dam in Zambia/Zimbabwe (180.6 cu $\mathrm{km}$ ) and only $12 \mathrm{cu} \mathrm{km}$ more than Aswan High Dam of Egypt.

While the reservoir of a dam stores water and is usually situated at a place where it can receive a lot of rainfall, the canals take water from this reservoir to distant places where water is a scare commodity. It was, of course, contended on behalf of the petitioner that if the practice of water harvesting is resorted to and some check dams are constructed, there would really be no need for a high dam like Sardar Sarovar. The answer to this given by the respondent is that water harvesting serves a useful purpose but it cannot ensure adequate supply to meet all the requirements of the people. Water harvesting means to collect, preserve and use the rain water. The problem of the area in question is that there is deficient rainfall and small scale water harvesting projects may not be adequate. During the non rainy days, one of the essential ingredients of water harvesting is the storing of water. It will not be wrong to say that the biggest dams to the smallest percolating tanks meant to tap the rain water are nothing but water harvesting structures to function by receiving water from the common rainfall.

Dam serves a number of purposes. It stores water, generates electricity and releases water throughout the year and at times of scarcity.

Its storage capacity is meant to control floods and the canal system which emanates therefrom is meant to convey and provide water for drinking, agriculture and industry. In addition thereto, it can also be a source of generating hydro-power. Dam has, therefore, necessarily to be regarded as an infrastructural project.

There are three stages with regard to the undertaking of an infrastructural project. One is conception or planning, second is decision to undertake the project and the third is the execution of 
the project. The conception and the decision to undertake a project is to be regarded as a policy decision. While there is always a need for such projects not being unduly delayed, it is at the same time expected that as thorough a study as is possible will be undertaken before a decision is taken to start a project.

Once such a considered decision is taken, the proper execution of the same should be taken expeditiously. It is for the Government to decide how to do its job. When it has put a system in place for the execution of a project and such a system cannot be said to be arbitrary, then the only role which a Court may have to play is to see that the system works in the manner it was envisaged.

A project may be executed departmentally or by an outside agency.

The choice has to be of the Government. When it undertakes the execution itself, with or without the help of another organisation, it will be expected to undertake the exercise according to some procedure or principles. The NCA was constituted to give effect to the Award, various sub-groups have been established under the NCA and to look after the grievances of the resettled oustees and each State has set up a Grievance Redressal Machinery. Over and above the NCA is the Review Committee. There is no reason now to assume that these authorities will not function properly. In our opinion the Court should have no role to play.

It is now well-settled that the courts, in the exercise of their jurisdiction, will not transgress into the field of policy decision. Whether to have an infrastructural project or not and what is the type of project to be undertaken and how it has to be executed, are part of policy making process and the Courts are ill equipped to adjudicate on a policy decision so undertaken. The Court, no doubt, has a duty to see that in the undertaking of a decision, no law is violated and peoples fundamental rights are not transgressed upon except to the extent permissible under the Constitution. Even then any challenge to such a policy decision must be before the execution of the project is undertaken. Any delay in the execution of the project means over run in costs and the decision to undertake a project, if challenged after its execution has commenced, should be thrown out at the very threshold on the ground of latches if the petitioner had the knowledge of such a decision and could have approached the Court at that time. Just because a petition is termed as a PIL does not mean that ordinary principles applicable to litigation will not apply. Latches is one of them.

Public Interest Litigation [PIL] was an innovation essentially to safeguard and protect the human rights of those people who were unable to protect themselves. With the passage of time the PIL jurisdiction has been ballooning so as to encompass within its ambit subjects such as probity in public life, granting of largess in the form of licences, protecting environment and the like. But the balloon should not be inflated so much that it bursts.

Public Interest Litigation should not be allowed to degenerate to becoming Publicity Interest Litigation or Private Inquisitiveness Litigation.

While exercising jurisdiction in PIL cases Court has not forsaken its duty and role as a Court of law dispensing justice in accordance with law. It is only where there has been a failure on the part of any authority in acting according to law or in non-action or acting in violation of the law that the Court has stepped in. No directions are issued which are in conflict with any legal provisions. Directions have, in appropriate cases, been given where the law is silent and inaction would result in violation of the Fundamental Rights or other Legal provisions.

While protecting the rights of the people from being violated in any manner utmost care has to be taken that the Court does not transgress its jurisdiction. There is in our Constitutional frame-work a fairly clear demarcation of powers. The Court has come down heavily whenever the executive has sought to impinge upon the Courts jurisdiction.

At the same time, in exercise of its enormous power the Court should not be called upon or undertake governmental duties or functions. The Courts cannot run the Government nor the administration indulge in abuse or non-use of power and get away with it. The essence of judicial review is a constitutional fundamental. The role of the higher judiciary under the constitution casts on it a great obligation as the sentinel to defend the values of the constitution and rights of Indians. The courts must, therefore, act within their judicially permissible limitations to uphold the rule of law and harness their power in public interest. It is precisely for this reason that it has been consistently held by this Court that in matters of policy the Court will not interfere. When there is a valid law requiring the Government to act in a particular manner the Court ought not to, without striking down the law, 
give any direction which is not in accordance with law. In other words the Court itself is not above the law.

In respect of public projects and policies which are initiated by the Government the Courts should not become an approval authority. Normally such decisions are taken by the Government after due care and consideration. In a democracy welfare of the people at large, and not merely of a small section of the society, has to be the concern of a responsible Government. If a considered policy decision has been taken, which is not in conflict with any law or is not mala fide, it will not be in Public Interest to require the Court to go into and investigate those areas which are the function of the executive. For any project which is approved after due deliberation the Court should refrain from being asked to review the decision just because a petitioner in filing a PIL alleges that such a decision should not have been taken because an opposite view against the undertaking of the project, which view may have been considered by the Government, is possible. When two or more options or views are possible and after considering them the Government takes a policy decision it is then not the function of the Court to go into the matter afresh and, in a way, sit in appeal over such a policy decision.

What the petitioner wants the Court to do in this case is precisely that. The facts enumerated hereinabove clearly indicate that the Central Government had taken a decision to construct the Dam as that was the only solution available to it for providing water to water scare areas. It was known at that time that people will be displaced and will have to be rehabilitated. There is no material to enable this Court to come to the conclusion that the decision was mala fide. A hard decision need not necessarily be a bad decision.

Furthermore environment concern has not only to be of the area which is going to be submerged and its surrounding area. The impact on environment should be seen in relation to the project as a whole. While an area of land will submerge but the construction of the Dam will result in multifold improvement in the environment of the areas where the canal waters will reach. Apart from bringing drinking water within easy reach the supply of water to Rajasthan will also help in checking the advancement of the Thar Desert. Human habitation will increase there which, in turn, will help in protecting the so far porous border with Pakistan.

While considering Gujarats demand for water, the Government had reports that with the construction of a high dam on the river Narmada, water could not only be taken to the scarcity areas of Northern Gujarat, Saurashtra and parts of Kutch but some water could also be supplied to Rajasthan.

Conflicting rights had to be considered. If for one set of people namely those of Gujarat, there was only one solution, namely, construction of a dam, the same would have an adverse effect on another set of people whose houses and agricultural land would be submerged in water. It is because of this conflicting interest that considerable time was taken before the project was finally cleared in 1987. Perhaps the need for giving the green signal was that while for the people of Gujarat, there was no other solution but to provide them with water from Narmada, the hardships of oustees from Madhya Pradesh could be mitigated by providing them with alternative lands, sites and compensation. In governance of the State, such decisions have to be taken where there are conflicting interests. When a decision is taken by the Government after due consideration and full application of mind, the Court is not to sit in appeal over such decision.

Since long the people of India have been deriving the benefits of the river valley projects. At the time of independence, food-grain was being imported into India but with the passage of time and the construction of more dams, the position has been reversed. The large-scale river valley projects per se all over the country have made India more than self- sufficient in food. Famines which used to occur have now become a thing of the past. Considering the benefits which have been reaped by the people all over India with the construction of the dams, the Government cannot be faulted with deciding to construct the high dam on the river Narmada with a view to provide water not only to the scarcity areas of Gujarat but also to the small areas of the State of Rajasthan where the shortage of water has been there since the time immemorial.

In the case of projects of national importance where Union of India and/or more than one State(s) are involved and the project would benefit a large section of the society and there is evidence to show that the said project had been contemplated and considered over a period of time at the highest level 
of the States and the Union of India and more so when the project is evaluated and approval granted by the Planning Commission, then there should be no occasion for any Court carrying out any review of the same or directing its review by any outside or independent agency or body. In a democratic set up, it is for the elected Government to decide what project should be undertaken for the benefit of the people. Once such a decision had been taken that unless and until it can be proved or shown that there is a blatant illegality in the undertaking of the project or in its execution, the Court ought not to interfere with the execution of the project.

Displacement of people living on the proposed project sites and the areas to be submerged is an important issue. Most of the hydrology projects are located in remote and in-accessible areas, where local population is, like in the present case, either illiterate or having marginal means of employment and the per capita income of the families is low. It is a fact that people are displaced by projects from their ancestral homes.

Displacement of these people would undoubtedly disconnect them from their past, culture, custom and traditions, but then it becomes necessary to harvest a river for larger good. A natural river is not only meant for the people close by but it should be for the benefit of those who can make use of it, being away from it or near by. Realising the fact that displacement of these people would disconnect them from their past, culture, custom and traditions, the moment any village is earmarked for take over for dam or any other developmental activity, the project implementing authorities have to implement R\&R programmes. The R\&R plans are required to be specially drafted and implemented to mitigate problems whatsoever relating to all, whether rich or poor, land owner or encroacher, farmer or tenant, employee or employer, tribal or non-tribal. A properly drafted R\&R plan would improve living standards of displaced persons after displacement.

For example residents of villages around Bhakra Nangal Dam, Nagarjun Sagar Dam, Tehri, Bhillai Steel Plant, Bokaro and Bala Iron and Steel Plant and numerous other developmental sites are better off than people living in villages in whose vicinity no development project came in. It is not fair that tribals and the people in un-developed villages should continue in the same condition without ever enjoying the fruits of science and technology for better health and have a higher quality of life style. Should they not be encouraged to seek greener pastures elsewhere, if they can have access to it, either through their own efforts due to information exchange or due to outside compulsions. It is with this object in view that the R\&R plans which are developed are meant to ensure that those who move must be better off in the new locations at Government cost. In the present case, the R\&R packages of the States, specially of Gujarat, are such that the living conditions of the oustees will be much better than what they had in their tribal hamlets.

Loss of forest because of any activity is undoubtedly harmful. Without going into the question as to whether the loss of forest due to river valley project because of submergence is negligible, compared to de- forestation due to other reasons like cutting of trees for fuel, it is true that large dams cause submergence leading to loss of forest areas. But it cannot be ignored and it is important to note that these large dams also cause conversion of waste land into agricultural land and making the area greener. Large dams can also become instruments in improving the environment, as has been the case in the Western Rajasthan, which transformed into a green area because of Indira Gandhi Canal, which draws water from Bhakhra Nangal Dam. This project not only allows the farmers to grow crops in deserts but also checks the spread of Thar desert in adjoining areas of Punjab and Haryana.

Environmental and ecological consideration must, of course, be given due consideration but with proper channellisation of developmental activities ecology and environment can be enhanced. For example, Periyar Dam Reservoir has become an elephant sanctuary with thick green forests all round while at the same time wiped out famines that used to haunt the district of Madurai in Tamil Nadu before its construction. Similarly Krishnarajasagar Dam which has turned the Mandya district which was once covered with shrub forests with wild beasts into a prosperous one with green paddy and sugarcane fields all round.

So far a number of such river valley projects have been undertaken in all parts of India. The petitioner has not been able to point out a single instance where the construction of a Dam has, on the whole, had an adverse environmental impact. On the contrary the environment has improved. That being so there is no reason to suspect, with all the experience gained so far, that the position here will be any different and there will not be overall improvement and prosperity. It should not be forgotten 
that poverty is regarded as one of the causes of degradation of environment. With improved irrigation system the people will prosper. The construction of Bhakra Dam is a shining example for all to see how the backward area of erstwhile undivided Punjab has now become the granary of India with improved environment than what was there before the completion of the Bhakra Nangal project.

The Award of the Tribunal is binding on the States concerned. The said Award also envisages the relief and rehabilitation measures which are to be undertaken. If for any reason, any of the State Governments involved lag behind in providing adequate relief and rehabilitation then the proper course, for a Court to take, would be to direct the Awards implementation and not to stop the execution of the project. This Court, as a Federal Court of the country specially in a case of inter-State river dispute where an Award had been made, has to ensure that the binding Award is implemented. In this regard, the Court would have the jurisdiction to issue necessary directions to the State which, though bound, chooses not to carry out its obligations under the Award. Just as an ordinary litigant is bound by the decree, similarly a State is bound by the Award. Just as the execution of a decree can be ordered, similarly, the implementation of the Award can be directed. If there is a short fall in carrying out the R\&R measures, a time bound direction can and should be given in order to ensure the implementation of the Award. Putting the project on hold is no solution. It only encourages recalcitrant State to flout and not implement the award with impunity. This certainly cannot be permitted. Nor is it desirable in the national interest that where fundamental right to life of the people who continue to suffer due to shortage of water to such an extent that even the drinking water becomes scarce, non-cooperation of a State results in the stagnation of the project.

The clamour for the early completion of the project and for the water to flow in the canal is not by Gujarat but is also raised by Rajasthan.

As per Clause 3 of the final decision of the Tribunal published in the Gazette notification of India dated 12th December, 1979, the State of Rajasthan has been allocated 0.5 MAF of Narmada water in national interest from Sardar Sarovar Dam. This was allocated to the State of Rajasthan to utilise the same for irrigation and drinking purposes in the arid and drought-prone areas of Jalore and Barmer districts of Rajasthan situated on the international border with Pakistan, which have no other available source of water.

Water is the basic need for the survival of human beings and is part of right of life and human rights as enshrined in Article 21 of the Constitution of India and can be served only by providing source of water where there is none. The Resolution of the U.N.O. in 1977 to which India is a signatory, during the United Nations Water Conference resolved unanimously inter alia as under:

All people, whatever their stage of development and their social and economic conditions, have the right to have access to drinking water in quantum and of a quality equal to their basic needs.

Water is being made available by the State of Rajasthan through tankers to the civilians of these areas once in four days during summer season in quantity, which is just sufficient for their survival. The districts of Barmer and Jalore are part of Thar Desert and on account of scarcity of water the desert area is increasing every year. It is a matter of great concern that even after half a century of freedom, water is not available to all citizens even for their basic drinking necessity violating the human right resolution of U.N.O. and Article 21 of the Constitution of India. Water in the rivers of India has great potentiality to change the miserable condition of the arid, drought-prone and border areas of India.

The availability of drinking water will benefit about 1.91 lac of people residing in 124 villages in arid and drought-prone border areas of Jalore and Barmer districts of Rajasthan who have no other source of water and are suffering grave hardship.

As already seen, the State of Madhya Pradesh is keen for the reduction of the dams height to 436 $\mathrm{ft}$. Apart from Gujarat and Rajasthan the State of Maharashtra also is not agreeable to this. The only benefit from the project which Rajasthan get is its share of hydel power from the project.

The lowering of the height from $455 \mathrm{ft}$. to $436 \mathrm{ft}$. will take away this benefit even though 9399 hectares of its land will be submerged. With the reduction of height to $436 \mathrm{ft}$. not only will there be loss of power generation but it would also render the generation of power seasonal and not throughout the year.

One of the indicators of the living standard of people is the per capita consumption of electricity. There is, however, perennial shortage of power in India and, therefore, it is necessary that the 
generation increases. The world over, countries having rich water and river systems have effectively exploited these for hydel power generation. In India, the share of hydel power in the total power generated was as high as 50\% in the year 1962-63 but the share of hydel power started declining rapidly after 1980. There is more reliance now on thermal power projects. But these thermal power projects use fossil fuels, which are not only depleting fast but also contribute towards environmental pollution. Global warming due to the greenhouse effect has become a major cause of concern. One of the various factors responsible for this is the burning of fossil fuel in thermal power plants.

There is, therefore, international concern for reduction of greenhouse gases which is shared by the World Bank resulting in the restriction of sanction of funds for thermal power projects. On the other hand, the hydel powers contribution in the greenhouse effect is negligible and it can be termed ecology friendly. Not only this but the cost of generation of electricity in hydel projects is significantly less. The Award of the Tribunal has taken all these factors into consideration while determining the height of the dam at $455 \mathrm{ft}$. Giving the option of generating eco-friendly electricity and substituting it by thermal power may not, therefore, be the best option.

Perhaps the setting up of a thermal plant may not displace as many families as a hydel project may but at the same time the pollution caused by the thermal plant and the adverse affect on the neighbourhood could be far greater than the inconvenience caused in shifting and rehabilitating the oustees of a reservoir.

There is and has been in the recent past protests and agitations not only against hydel projects but also against the setting up of nuclear or thermal power plants. In each case reasons are put forth against the execution of the proposed project either as being dangerous (in case of nuclear) or causing pollution and ecological degradation (in the case of thermal) or rendering people homeless and posses adverse environment impacts as has been argued in the present case. But then electricity has to be generated and one or more of these options exercised. What option to exercise, in our Constitutional framework, is for the Government to decide keeping various factors in mind. In the present case, a considered decision has been taken and an Award made whereby a high dam having an FRL of $455 \mathrm{ft}$. with capability of developing hydel power to be constructed. In the facts and circumstances enumerated hereinabove, even if this Court could go into the question, the decision so taken cannot be faulted.

DIRECTIONS While issuing directions and disposing of this case, two conditions have to be kept in mind, (i) the completion of project at the earliest and (ii) ensuring compliance with conditions on which clearance of the project was given including completion of relief and rehabilitation work and taking of ameliorative and compensatory measures for environmental protection in compliance with the scheme framed by the Government thereby protecting the rights under Article 21 of the Constitution. Keeping these principles in view, we issue the following directions.

1) Construction of the dam will continue as per the Award of the Tribunal.

2) As the Relief and Rehabilitation Sub-group has cleared the construction up to 90 meters, the same can be undertaken immediately. Further raising of the height will be only pari passu with the implementation of the relief and rehabilitation and on the clearance by the Relief and Rehabilitation Sub-group. The Relief and Rehabilitation Sub-Group will give clearance of further construction after consulting the three Grievances Redressal Authorities.

3) The Environment Sub-group under the Secretary, Ministry of Environment \& Forests, Government of India will consider and give, at each stage of the construction of the dam, environment clearance before further construction beyond 90 meters can be undertaken.

4) The permission to raise the dam height beyond 90 meters will be given by the Narmada Control Authority, from time to time, after it obtains the above-mentioned clearances from the Relief and Rehabilitation Sub-group and the Environment Sub-group.

5) The reports of the Grievances Redressal Authorities, and of Madhya Pradesh in particular, shows that there is a considerable slackness in the work of identification of land, acquisition of suitable land and the consequent steps necessary to be taken to rehabilitate the project oustees. We direct the States of Madhya Pradesh, Maharashtra and Gujarat to implement the Award and give relief and rehabilitation to the oustees in terms of the packages offered by them and these States shall 
comply with any direction in this regard which is given either by the NCA or the Review Committee or the Grievances Redressal Authorities.

6) Even though there has been substantial compliance with the conditions imposed under the environment clearance the NCA and the Environment Sub-group will continue to monitor and ensure that all steps are taken not only to protect but to restore and improve the environment.

7) The NCA will within four weeks from today draw up an Action Plan in relation to further construction and the relief and rehabilitation work to be undertaken. Such an Action Plan will fix a time frame so as to ensure relief and rehabilitation pari passu with the increase in the height of the dam. Each State shall abide by the terms of the action plan so prepared by the NCA and in the event of any dispute or difficulty arising, representation may be made to the Review Committee. However, each State shall be bound to comply with the directions of the NCA with regard to the acquisition of land for the purpose of relief and rehabilitation to the extent and within the period specified by the NCA.

8) The Review Committee shall meet whenever required to do so in the event of there being any un-resolved dispute on an issue which is before the NCA. In any event the Review Committee shall meet at least once in three months so as to oversee the progress of construction of the dam and implementation of the R\&R programmes.

If for any reason serious differences in implementation of the Award arise and the same cannot be resolved in the Review Committee, the Committee may refer the same to the Prime Minister whose decision, in respect thereof, shall be final and binding on all concerned.

9) The Grievances Redressal Authorities will be at liberty, in case the need arises, to issue appropriate directions to the respective States for due implementation of the R\&R programmes and in case of non- implementation of its directions, the GRAs will be at liberty to approach the Review Committee for appropriate orders.

10) Every endeavour shall be made to see that the project is completed as expeditiously as possible.

\section{Dams and Development: \\ A New Framework for Decision-Making \\ The Report of the World Commission on Dams \\ An Overview - November 16 2000, http://www.dams.org}

In April 1997, with support from the World Bank and IUCN-The World Conservation Union, representatives of diverse interests met in Gland, Switzerland, in light of a recent World Bank report, to discuss highly controversial issues associated with large dams. The workshop brought together 39 participants from governments, the private sector, international financial institutions, civil society organisations and affected people. One proposal that came out of the meeting was for all parties to work together in establishing the World Commission on Dams (WCD) with a mandate to:

- review the development effectiveness of large dams and assess alternatives for water resources and energy development; and

- develop internationally acceptable criteria, guidelines and standards, where appropriate, for the planning, design, appraisal, construction, operation, monitoring and decommissioning of dams

The WCD began its work in May 1998 under the Chairmanship of Prof. Kader Asmal, who was then South Africa's Minister of Water Affairs and Forestry; its members were chosen to reflect regional diversity, expertise and stakeholder perspectives....

\section{Dams and Development -- An Introduction}

As we start the new century, one-third of the countries in the world rely on hydropower for more than half their electricity supply, and large dams generate $19 \%$ of electricity overall. Half the world's large dams were built exclusively or primarily for irrigation, and some $30-40 \%$ of the 271 million hectares irrigated worldwide rely on dams. Dams have been promoted as an important means of meeting perceived needs for water and energy services and as long-term, strategic investments with the ability to deliver multiple benefits. Some of these additional benefits are typical of all large public infrastructure projects, while others are unique to dams and specific to particular projects. 
Regional development, job creation, and fostering an industry base with export capability are most often cited as additional considerations for building large dams. Other goals include creating income from export earnings, either through direct sales of electricity or by selling cash crops or processed products from electricity-intensive industry such as aluminium refining. Clearly, dams can play an important role in meeting people's needs.

But the last 50 years have also highlighted the performance and the social and environmental impacts of large dams. They have fragmented and transformed the world's rivers, while global estimates suggest that 40-80 million people have been displaced by reservoirs.

As the basis for decision-making has become more open, inclusive and transparent in many countries, the decision to build a large dam has been increasingly contested, to the point where the future of large dam-building in many countries is in question. The enormous investments and widespread impacts of large dams have seen conflicts flare up over the siting and impacts of large dams - both those in place and those on the drawing board, making large dams one of the most hotly contested issues in sustainable development today.

Proponents point to the social and economic development demands that dams are intended to meet, such as irrigation, electricity, flood control and water supply. Opponents point to the adverse impacts of dams, such as debt burden, cost overruns, displacement and impoverishment of people, destruction of important ecosystems and fishery resources, and the inequitable sharing of costs and benefits.

With these conflicts and pressures in mind, the World Commission on Dams began its work in May 1998. One of the Commissioners' first points of agreement was that dams are only a means to an end. What is that end? How central are the challenges that large dams set out to meet? And how well can they meet these challenges?

The WCD concluded that the 'end' that any project achieves must be the sustainable improvement of human welfare. This means a significant advance of human development on a basis that is economically viable, socially equitable and environmentally sustainable. If a large dam is the best way to achieve this goal, it deserves support. Where other options offer better solutions, they should be favoured over large dams. Thus the debate around dams challenges views of how societies develop and manage water resources in the broader context of development choices.

After more than two years of intense study, dialogue with those for and against large dams, and reflection, the Commission believes there can no longer be any justifiable doubt about five key points:

1.Dams have made an important and significant contribution to human development, and the benefits derived from them have been considerable

2.In too many cases an unacceptable and often unnecessary price has been paid to secure those benefits, especially in social and environmental terms, by people displaced, by communities downstream, by taxpayers and by the natural environment.

3. Lack of equity in the distribution of benefits has called into question the value of many dams in meeting water and energy development needs when compared with the alternatives

4. By bringing to the table all those whose rights are involved and who bear the risks associated with different options for water and energy resources development, the conditions for a positive resolution of competing interests and conflicts are created

5. Negotiating outcomes will greatly improve the development effectiveness of water and energy projects by eliminating unfavourable projects at an early stage, and by offering as a choice only those options that key stakeholders agree represent the best ones to meet the needs in question

\section{The Changing Context}

The Commission's overall conclusions about large dams are grounded in a basic understanding about the relationships between water, dams and development. One of the greatest challenges facing 
the world in this new century is rethinking the management of freshwater resources. A number of global initiatives and reports have documented the dramatic impact of withdrawals from the world's lakes, rivers and underground aquifers. Total annual freshwater withdrawals today are estimated at 3800 cubic kilometres - twice as much as 50 years ago.

The imperative to supply growing populations and economies with water when groundwater is depleted, water quality is declining, and there are increasingly severe limits to surface water extraction has brought sustainable water resources management to the top of the global development agenda. These pressures on water contain a wide range of threats, but they also generate the momentum for new opportunities and policy changes.

During the past few decades, societies have moved from seeing water as a free good to viewing it as a limited natural resource and, more recently, as an economic good and a human right. Thus water is recognised as a scarce natural resource, which gives rise to equity considerations in its allocation.

How much water is required for one more person, or one more urban dweller? Water use per capita varies greatly in different regions of the world. Although what constitutes an appropriate level of domestic water consumption is influenced by climate and culture, several international agencies and experts have proposed 50 litres per person per day as enough to cover basic human requirements for drinking, sanitation, bathing and cooking. In 1990, more than a billion people had less than that. At the same time, households in industrial countries and wealthy city-dwellers in developing countries were using 4-14 times as much.

Dams and Development notes the forecasts of leading analysts who foresee growing competition for water to meet demands for agriculture, industry and drinking water.

- Competition will increase among the three largest users in global terms agriculture (67\%), industry (19\%) and municipal/residential $(9 \%)$ uses - and these all will continue to draw from the water needed to sustain natural systems

- A consumption factor that may be significant in dry climates is evaporation from reservoirs, estimated to be close to $5 \%$ of total water withdrawals

- A projection prepared for the Vision for Water and Food suggests that irrigation alone may require an increase in water supplies in the range of $15-20 \%$ by 2025

- By 2025 there will be a total of 3.5 billion people living in water-stressed countries. Empirical evidence suggests that limited water supplies, combined with current agricultural practices and population growth, are a barrier to meeting the goal of food self-sufficiency in more and more countries, increasing the attention paid to food security and the security of other environmental resources

- Two billion people lack electricity, and electricity demand in developing economies continues to rise

- Freshwater species, especially fish, are increasingly threatened, a significant percentage of wetlands have already been lost, and the capacity of aquatic ecosystems to produce many of the goods and services on which societies depend is rapidly declining, making water for nature an essential consideration

During the last century, much of the world turned to dams to help meet escalating demands for water. Indeed, from the 1930s to the 1970s the construction of large dams became - in the eyes of many - synonymous with development and economic progress. Viewed as symbols of modernisation and humanity's ability to control and use nature's resources, dam construction saw a dramatic increase.

... Hydropower accounts for more than $90 \%$ of the total electricity supply in 24 countries, such as Brazil and Norway. Half of the world's large dams are built exclusively for irrigation, and dams are estimated to contribute to $12-16 \%$ of world food production. In addition, in at least 75 countries large dams have been built to control floods. For many nations, dams remain the largest single investment project in the country.

These hydropower, irrigation, water supply and flood control services were widely seen as sufficient to justify the significant investments made in dams, and other benefits were often cited as well. These included the impact of economic prosperity on a region due to multiple cropping, rural electrification and the expansion of physical and social infrastructure such as roads and schools. The benefits were 
seen as self-evident. When balanced with the construction and operational costs - in economic and financial terms - these benefits were seen to justify dams as the most competitive option.

\section{What Is the Debate About?}

As noted earlier, the reported returns on the investments made in dams have increasingly been questioned. The notion of costs versus reported benefits emerged as a public concern, given growing experience and knowledge about the performance and consequences of dams. Driven by research and information on the impacts of dams on people, river basins and ecosystems, as well as data on economic performance, opposition began to grow. During the early stages of this process, debate and controversy focused on specific dams and their local impacts. But gradually these locally driven conflicts began to evolve into a more general and ultimately a global debate about dams.

The issues surrounding dams are the same issues that surround water, and how water-related decisions are made, as well as how development effectiveness is assessed. There is little public controversy about the choice between an embankment dam or a gravity dam, or about whether to use earth, concrete or rock-fill. The problems all relate to what the dam will do to river flow and to rights of access to water and river resources; to whether the dam will uproot existing settlements, disrupt the culture and sources of livelihood of local communities, or deplete or degrade environmental resources; and to whether the dam is the best economic investment of public funds and resources.

The debate is partly about what occurred in the past and continues to occur today, and partly about what may unfold in the future if more dams are built. In some countries, it is driven primarily by specific social or environmental concerns; in others, by broader development considerations. In the United States, where the rate of decommissioning is greater than the rate of construction of new large dams, the debate is perhaps as intense as - but qualitatively different from - the debate in India, which along with China is now building the most dams.

The two principal poles in the debate illustrate the range of views on past experience with large dams. One perspective focuses on the gap between the promised benefits of a dam and the actual outcomes. The other view looks at the challenges of water and energy development from a perspective of 'nation building' and resource allocation. To proponents, the answer to any questions about past performance is self-evident, as they maintain that dams have generally performed well as an integral part of water and energy resource development strategies in over 140 nations and, with exceptions, have provided an indispensable range of water and energy services.

Opponents contend that better, cheaper, more benign options for meeting water and energy needs exist and have been frequently ignored, from small-scale, decentralised water supply and electricity options to large-scale end-use efficiency and demand-side management options. Dams, it is argued, have often been selected over other options that may meet water or energy goals at lower cost or that may offer development benefits that are more sustainable and more equitable.

Although there may be agreement on such issues as the need to take environmental and social costs of dams more seriously and to consult systematically with affected people, deep fault lines still separate critics and proponents on a number of financial, economic, social and environmental issues. Among the most intractable are:

- the extent to which alternatives to dams are viable for achieving various development goals, and whether alternatives are complementary or mutually exclusive

- the extent to which adverse environmental and social impacts are acceptable

- the degree to which adverse environmental and social impacts can be avoided or mitigated; and

- the extent to which local consent should govern development decisions in the future

The decision to build a large dam today is rarely only a local or national one. The debate has been transformed from a local process of assessing costs and benefits to one in which dams in general are the focus of a global debate about development strategies and choices.

What Did the WCD Global Review of Large Dams Find? 
The degree to which large dams in the WCD Knowledge Base have delivered services and net benefits as planned varied substantially from one project to the next, with a considerable portion falling short of physical and economic targets. In spite of this, the services produced by dams are considerable, as noted earlier. Irrespective of performance against targets, the Knowledge Base also confirmed the longevity of large dams, with many continuing to generate benefits after 30-40 years of operation.

A sectoral review of technical, financial and economic performance of dams in the Knowledge Base in terms of planned versus actual performance suggested the following:

- Large dams designed to deliver irrigation services have typically fallen short of physical targets, did not recover their costs and have been less profitable in economic terms than expected

- Large dams built to deliver hydropower tend to perform close to but still below targets for power generation, generally meet their financial targets but demonstrate variable economic performance relative to targets, and include a number of notable under- and over-performers

- Large dams built for municipal and industrial water supply have generally fallen short of intended targets for timing and delivery of bulk water supply and have exhibited poor financial cost recovery and economic performance

- Large dams with a flood control component have provided important benefits in this regard, but at the same time have led to greater vulnerability to flood hazards due to increased settlement in areas still at risk from floods, and in some cases have worsened flood damages for a number of reasons, including poor operation of dams

- Large dams that serve multiple purposes also under-achieve relative to targets, in some cases exceeding the shortfalls registered by single-purpose projects, demonstrating that the targets established were often over-optimistic

The review of performance suggested two further findings:

- Large dams in the Knowledge Base have a marked tendency towards schedule delays and significant cost overruns

- Growing concern over the cost and effectiveness of large dams and associated structural measures have led to the adoption of integrated flood management that emphasises a mix of policy and non-structural measures to reduce the vulnerability of communities to flooding

The review also examined factors related to the physical sustainability of large dams and their benefits and confirmed that:

- Ensuring the safety of dams will require increasing attention and investment as the stock of dams ages, maintenance costs rise and climate change possibly alters the hydrological regime used as a basis for the design of dam spillways

- Sedimentation and the consequent long-term loss of storage is a serious concern globally, and the effects will be particularly felt by basins with high geological or human-induced erosion rates, dams in the lower reaches of rivers and dams with smaller storage volumes

- Waterlogging and salinity affect one-fifth of irrigated land globally including land irrigated by large dams - and have severe, long-term and often permanent impacts on land, agriculture and livelihoods where rehabilitation is not undertaken

Using the information on the performance of large dams collected in the WCD Knowledge Base, the Commission's report shows that there is considerable scope for improving the selection of projects and the operation of existing large dams and their associated infrastructure. Considering the enormous capital invested in large dams, it is surprising that substantive evaluations of project performance are few in number, narrow in scope and poorly integrated across impact categories and scales. 


\section{Ecosystems and Large Dams}

The generic nature of the impacts of large dams on ecosystems, biodiversity and downstream livelihoods is increasingly well known. From the WCD Knowledge Base it is clear that large dams have led to:

- the loss of forests and wildlife habitat, the loss of species populations and the degradation of upstream catchment areas due to inundation of the reservoir area

- the loss of aquatic biodiversity, of upstream and downstream fisheries, and of the services of downstream floodplains, wetlands, and riverine, estuarine and adjacent marine ecosystems; and

- cumulative impacts on water quality, natural flooding and species composition where a number of dams are sited on the same river

On balance, the ecosystem impacts are more negative than positive and they have led, in many cases, to significant and irreversible loss of species and ecosystems. In some cases, however, enhancement of ecosystem values does occur, through the creation of new wetland habitat and the fishing and recreational opportunities provided by new reservoirs.

The Commission found that reservoirs sampled so far by scientists all emit greenhouse gases, as do natural lakes, due to the rotting of vegetation and carbon inflows from the catchment. The scale of such emissions is highly variable. Preliminary data from a Case Study hydropower dam in Brazil show that the gross level of these emissions is significant, relative to emissions from equivalent thermal power plants.

However, in other reservoirs studied (notably those in boreal zones), gross emissions of greenhouse gases are significantly lower than the thermal alternative. A full comparison would require measurements of the emissions from natural pre-impoundment habitats. More research is needed on a case-by-case basis to demonstrate the capacity of hydropower to offset climate change.

Efforts to date to counter the ecosystem impacts of large dams have met with limited success due to the lack of attention to anticipating and avoiding such impacts, the poor quality and uncertainty of predictions, the difficulty of coping with all impacts, and the only partial implementation and success of mitigation measures. More specifically:

- It is not possible to mitigate many of the impacts of reservoir creation on terrestrial ecosystems and biodiversity, and efforts to 'rescue' wildlife have met with little longterm success

- The use of fish passes to mitigate the blockage of migratory fish has had little success, as the technology has often not been tailored to specific sites and species

- Good mitigation results from a good information base; early co-operation between ecologists, the dam design team and affected people; and regular monitoring and feedback on the effectiveness of mitigation measures

- Environmental flow requirements (which include managed flood releases) are increasingly used to reduce the impacts of changed streamflow regimes on aquatic, floodplain and coastal ecosystems downstream

Given the limited success of traditional mitigation measures, increased attention through legislation is now given to avoidance or minimisation of ecological impacts through setting aside particular river segments or basins in their natural state and through the selection of alternative projects, sites or designs. In addition, governments are experimenting with a 'compensatory' approach, offsetting the loss of ecosystems and biodiversity caused by a large dam through investment in conservation and regeneration measures and through protection of other threatened sites of equivalent ecological value.

Finally, in a number of industrialised countries, but particularly in the United States, ecosystem restoration is being implemented as a result of the decommissioning of large and small dams.

\section{People and Large Dams}

In terms of the social impacts of dams, the Commission found that the negative effects were frequently neither adequately assessed nor accounted for. The range of these impacts is substantial, 
including on the lives, livelihoods and health of the affected communities dependent on the riverine environment:

- Some 40-80 million people have been physically displaced by dams worldwide

- Millions of people living downstream from dams - particularly those reliant on natural floodplain function and fisheries - have also suffered serious harm to their livelihoods and the future productivity of their resources has been put at risk

- Many of the displaced were not recognised (or enumerated) as such, and therefore were not resettled or compensated

- Where compensation was provided it was often inadequate, and where the physically displaced were enumerated, many were not included in resettlement programmes

- Those who were resettled rarely had their livelihoods restored, as resettlement programmes have focused on physical relocation rather than the economic and social development of the displaced

- The larger the magnitude of displacement, the less likely it is that even the livelihoods of affected communities can be restored

- Even in the 1990s, impacts on downstream livelihoods were, in many cases, not adequately assessed or addressed in the planning and design of large dams

In sum, the Knowledge Base demonstrated a generalised lack of commitment or lack of capacity to cope with displacement. In addition, large dams in the Knowledge Base have also had significant adverse effects on cultural heritage through the loss of cultural resources of local communities and the submergence and degradation of plant and animal remains, burial sites and archaeological monuments.

The Knowledge Base indicated that the poor, other vulnerable groups and future generations are likely to bear a disproportionate share of the social and environmental costs of large dam projects without gaining a commensurate share of the economic benefits:

- Indigenous and tribal peoples and vulnerable ethnic minorities have suffered disproportionate levels of displacement and negative impacts on livelihood, culture and spiritual existence

- Affected populations living near reservoirs as well as displaced people and downstream communities have often faced adverse health and livelihood outcomes from environmental change and social disruption

- Among affected communities, gender gaps have widened and women have frequently borne a disproportionate share of the social costs and were often discriminated against in the sharing of benefits

Where such inequities exist in the distribution of the costs and benefits, the Global Review emphasises that the 'balance-sheet' approach to adding up the costs and benefits is increasingly seen as unacceptable on equity grounds and as a poor means of choosing the 'best' projects. In any event, the true economic profitability of large dam projects remains elusive, as the environmental and social costs of large dams were poorly accounted for in economic terms.

More to the point, failures to account adequately for these impacts and to fulfil commitments that were made have led to the impoverishment and suffering of millions, giving rise to growing opposition to dams by affected communities worldwide. Innovative examples of processes for making reparations and sharing project benefits are emerging that provide hope that past injustices can be remedied and future ones avoided.

\section{Options for Water and Energy Resources Development}

The Global Review examined the options for meeting energy, water and food needs in today's circumstances and the barriers and enabling conditions that determine choice or adoption of particular options. Many options currently exist - including demand-side management (DSM), supply efficiency, and new supply options. These can all improve or expand water and energy services and meet evolving development needs across all segments of society. Viewing these options in an integrated fashion, rather than for individual sectors, suggested the following general findings and lessons:

- Demand-side management options include reduced consumption, recycling and technological and policy options that promote efficiency of water and power at the 
point of end-use. DSM has significant untapped and universal potential and provides a major opportunity to reduce water stress and power requirements as well as achieve other benefits such as the reduction of greenhouse gas emissions.

- Improving system management can defer the need for new sources of supply by enhancing supply and conveyance efficiency. Needless loss of power and water can be avoided through reductions in water leakages from the system, keeping up with system maintenance and upgrading of control, transmission and distribution technology in the power sector

- Basin and catchment management through vegetative and structural measures offers an opportunity across all sectors to reduce sedimentation of reservoirs and canals and to manage the timing and quantity of peak, seasonal and annual flows, as well as groundwater recharge

- A number of supply options have emerged that are locally and environmentally appropriate, economically viable and acceptable to the public, including recycling, rainwater harvesting and wind power

The ability of various options to meet existing and future needs or to replace conventional supplies depends on the specific context, but in general they offer significant potential, individually and collectively.

\section{Decision-Making, Planning and Compliance}

As a development choice, large dams often became a focal point for the interests of politicians, dominant and centralised government agencies, international financing agencies and the dam-building industry. Involvement from civil society varied with the degree of debate and open political discourse in a country. However, dams in the WCD Knowledge Base reveal a generalised failure to recognise affected people as partners in the planning process, with rights, and to empower them to participate in the process.

Foreign assistance has accounted for less than $15 \%$ of total funding for dams in developing countries. Still, the funds provided - more than $\$ 4$ billion per year during the peak of lending in 197584 -played an important role in promoting and financing large dams in countries building only a few dams. These countries have often been vulnerable to conflicts between the interests of governments, donors and industry involved in foreign assistance programmes, on the one hand, and improved development outcomes for rural people, particularly the poor, on the other hand.

To a lesser extent this assistance has supported larger countries seeking to build many dams (including China, India and Brazil), primarily through the provision of finance for dam-building programmes. In shared river basins, the lack of agreements on water use is an increasing concern and cause for tension, particularly as demands grow and unilateral decisions by one country to build large dams alter water flows within a basin, with significant consequences for other riparian States.

Evaluation of the planning and project cycle for large dams revealed a series of limitations, risks and failures in the manner in which these facilities have been planned, operated and evaluated:

- Participation and transparency in planning processes for large dams frequently was neither inclusive nor open.

- Options assessment has been typically limited in scope and confined primarily to technical parameters and the narrow application of economic cost-benefit analyses

- The participation of affected people and the undertaking of environmental and social impact assessment have often occurred late in the process and were limited in scope

- The paucity of monitoring and evaluation activity once a large dam is built has impeded learning from experience

- Many countries have not yet established licensing periods that clarify the responsibilities of the owner towards the end of the dam's effective life

The net effect of these difficulties is that once a proposed dam project has passed preliminary technical and economic feasibility tests and attracted interest from government, external financing agencies or political interests, the momentum behind the project often prevails over further assessments. As a result, many dams were not built based on a comprehensive assessment and evaluation of the technical, financial and economic criteria applicable at the time, much less the social 
and environmental criteria that apply in today's context. That many such projects have not met standards applicable in either context is therefore not surprising, but nonetheless cause for concern.

Conflicts over dams stem also from the failure of dam proponents and financing agencies to fulfil commitments made, observe statutory regulations and abide by internal guidelines. In some cases, the opportunity for corruption provided by dams as large-scale infrastructure projects further distorted decision-making, planning and implementation. Whereas substantial improvements in policies, legal requirements and assessment guidelines have occurred, particularly in the 1990s, it appears that business is often conducted as usual when it comes to actual planning and decision-making. Moreover, where substantial differences arise between proponents and those potentially affected, efforts to modify plans and decisions often must resort to legal or other action outside the normal planning process. Regional Consultations held by the Commission underscored that past conflicts remain largely unresolved for a number of reasons, including poor experience with appeals, dispute resolution and recourse mechanisms.

Throughout the Global Review recent examples and illustrations of good practice are presented that form the basis of the Commission's optimism that these barriers are surmountable, and that these difficulties are not inevitable. As a means of reducing negative impacts and conflicts, these experiences indicate that there are opportunities, and indeed a responsibility, to:

- increase the efficiency of existing assets;

- avoid and minimise ecosystem impacts

- engage in participatory, multi-criteria analysis of development needs and options;

- ensure that displaced and project-affected peoples' livelihoods are improved

- resolve past inequities and injustices, and transform project-affected people into beneficiaries

- conduct regular monitoring and periodic review; and

- develop, apply and enforce incentives, sanctions and recourse mechanisms especially in the area of environmental and social performance

The Commission's recommendations deliver a way forward that can improve planning, decisionmaking and compliance, and thereby capitalise on the options available - whether technological, policy or institutional in nature - and provide economically efficient, socially equitable and environmentally sustainable solutions to meet future water and energy needs.

\section{How Can We Achieve Better Outcomes?}

To improve development outcomes in the future we need to look at proposed water and energy development projects in a much wider setting - a setting that reflects full knowledge and understanding of the benefits and impacts of large dam projects and alternative options for all parties. It means that we have to bring new voices, perspectives and criteria into decision-making, and we need to develop an approach that will build consensus around the decisions reached. This will result in fundamental changes in the way decisions are made.

Such a process must start with a clear understanding of the shared values, objectives and goals of development. The Commission grouped the core values informing its understanding of these issues under five main headings:

1. equity,

2. efficiency,

3. participatory decision-making,

4. sustainability and

5. accountability

These five values run through the entire report and are the foci of concerns raised by the evidence presented in the Global Review. They are also aligned with the international framework of norms articulated in the UN Declaration of Human Rights that the Commission cites as a powerful framework of internationally accepted standards.

Considerable support exists for rights, particularly basic human rights, to be considered as a fundamental reference point in any debate on dams - starting with the adoption of the Universal Declaration of Human Rights in 1948 and the related covenants adopted thereafter, through to the 
Declaration on the Right to Development adopted by the General Assembly in 1986 and the Rio Principles agreed to at the UN Conference on Environment and Development in 1992.

Given the significance of rights-related issues as well as the nature and magnitude of potential risks for all parties concerned, the Commission proposes that an approach based on 'recognition of rights' and 'assessment of risks' (particularly rights at risk) be developed as a tool for guiding future planning and decision-making. This will also provide a more effective framework for integrating the economic, social and environmental dimensions for options assessment and the planning and project cycles.

Clarifying the rights context for a proposed project is an essential step in identifying those legitimate claims and entitlements that might be affected by the proposed project - or indeed, its alternatives. It is also the basis for effective identification of stakeholder groups that are entitled to a formal role in the consultative process, and eventually in negotiating project-specific agreements relating, for example, to benefit sharing, resettlement or compensation.

The notion of risk adds an important dimension to understanding how, and to what extent, a project may have an impact on such rights. Traditional practice is to restrict the definition of risk to the risk of the developer or corporate investor in terms of capital invested and expected returns. These voluntary risk-takers have the capacity to define the level and type of risk they wish to take and explicitly to define its boundaries and acceptability. In contrast, as the Global Review showed, a far larger group often has risks imposed on them involuntarily and managed by others. Typically, these involuntary risk-bearers have little or no say in overall water and energy policy, in the choice of specific projects or in project design and implementation. The risks they face directly affect individual well-being, livelihoods, quality of life, even their spiritual world view and very survival.

Dealing with risks cannot be reduced to consulting actuarial tables or applying a mathematical formula. In the end, as in the case of rights and entitlements, they must be identified, articulated and addressed explicitly. This will require the acknowledgement of risk to be extended to a wider group than governments or developers in order to include both those affected by a project and the environment as a public good.

A rights-and-risks approach to options assessment and to the planning and project cycles presents an effective framework to determine who has a legitimate place at the negotiation table and what issues need to be on the agenda. It empowers decision-making processes based on the pursuit of negotiated outcomes, conducted in an open and transparent manner and inclusive of all legitimate actors involved in the issue, thereby helping to resolve the many and complex issues surrounding water, dams and development. While presenting greater demands at early stages of options assessment and project design, it leads to greater clarity and legitimacy for subsequent steps in decision-making and implementation.

Having laid the groundwork of five core values and a rights-and-risks approach, the Commission developed a constructive and innovative way forward for decision-making in the form of seven strategic priorities and corresponding policy principles. These are written in terms of the outcomes to be achieved. They are supported by a practical set of principles and guidelines designed for adoption, adaptation and use by all those involved in the dams debate. These move from a traditional top-down, technology-focused approach to advocate significant innovations in assessing options, managing existing dams, gaining public acceptance and negotiating and sharing benefits.

\section{Strategic Priorities for Decision-Making}

\section{Gaining Public Acceptance}

Public acceptance of key decisions is essential for equitable and sustainable water and energy resources development. Acceptance emerges from recognising rights, addressing risks, and safeguarding the entitlements of all groups of affected people, particularly indigenous and tribal peoples, women and other vulnerable groups.

Decision-making processes and mechanisms are used that enable informed participation by all groups of people, and result in the demonstrable acceptance of key decisions. Where projects affect indigenous and tribal peoples, such processes are guided by their free, prior and informed consent. 
- Recognition of rights and assessment of risks is the basis for the identification and inclusion of stakeholders in decision-making on energy and water resources development

- Access to information, legal and other support is available to all stakeholders, particularly indigenous and tribal peoples, women and other vulnerable groups, to enable their informed participation in decision-making processes

- Demonstrable public acceptance of all key decisions is achieved through agreements negotiated in an open and transparent process conducted in good faith and with the informed participation of all stakeholders

- Decisions on projects affecting indigenous and tribal peoples are guided by their free, prior and informed consent, achieved through formal and informal representative bodies.

\section{Comprehensive Options Assessment}

Alternatives to dams often do exist. To explore these alternatives, needs for water, food and energy are assessed and objectives clearly defined. The appropriate development response is identified from a range of possible options. The selection is based on a comprehensive and participatory assessment of the full range of policy, institutional and technical options.

In the assessment process, social and environmental aspects have the same significance as economic and financial factors. The options assessment process continues through all stages of planning, project development and operations.

- Development needs and objectives are clearly formulated through an open and participatory process before the identification and assessment of options for water and energy resource development

- Planning approaches that take into account the full range of development objectives are used to assess all policy, institutional, management and technical options before the decision to proceed with any programme or project

- Social and environmental aspects are given the same significance as technical, economic and financial factors in assessing options

- Increasing the effectiveness and sustainability of existing water, irrigation and energy systems is given priority in the options assessment process.

- If a dam is selected through such a comprehensive options assessment, social and environmental principles are applied in the review and selection of options throughout the detailed planning, design, construction and operation phases

\section{Sustaining Rivers and Livelihoods}

Rivers, watersheds and aquatic ecosystems are the biological engines of the planet. They are the basis for life and the livelihoods of local communities. Dams transform landscapes and create risks of irreversible impacts. Understanding, protecting and restoring ecosystems at river basin level is essential to foster equitable human development and the welfare of all species.

Options assessment and decision-making around river development prioritises the avoidance of impacts, followed by the minimisation and mitigation of harm to the health and integrity of the river system. Avoiding impacts through good site selection and project design is a priority. Releasing tailor-made environmental flows can help maintain downstream ecosystems and the communities that depend on them.

- A basin-wide understanding of the ecosystem's functions, values and requirements, and how community livelihoods depend on and influence them, is required before decisions on development options are made

- Decisions value ecosystem, social and health issues as an integral part of project and river basin development, and avoidance of impacts is given priority, in accordance with a precautionary approach 
- A national policy is developed for maintaining selected rivers with high ecosystem functions and values in their natural state. When reviewing alternative locations for dams on undeveloped rivers, priority is given to locations on tributaries

- Project options are selected that avoid significant impacts on threatened and endangered species. When impacts cannot be avoided, viable compensation measures are put in place that will result in a net gain for the species within the region

- Large dams provide for releasing environmental flows to help maintain downstream ecosystem integrity and community livelihoods and are designed, modified and operated accordingly

\section{Recognising Entitlements and Sharing Benefits}

Joint negotiations with adversely affected people result in mutually agreed and legally enforceable mitigation and development provisions. These provisions recognise entitlements that improve livelihoods and quality of life, and affected people are beneficiaries of the project.

Successful mitigation, resettlement and development are fundamental commitments and responsibilities of the State and the developer. They bear the onus to satisfy all affected people that moving from their current context and resources will improve their livelihoods. Accountability of responsible parties to agreed mitigation, resettlement and development provisions is ensured through legal means, such as contracts, and through accessible legal recourse at national and international levels.

- Recognition of rights and assessment of risks is the basis for identification and inclusion of adversely affected stakeholders in joint negotiations on mitigation, resettlement and development-related decision-making.

- Impact assessment includes all people in the reservoir, upstream, downstream and catchment areas whose properties, livelihoods and non-material resources are affected. It also includes those affected by dam-related infrastructure such as canals, transmission lines and resettlement developments

- All recognised adversely affected people negotiate mutually agreed, formal and legally enforceable mitigation, resettlement and development entitlements

- Adversely affected people are recognised as first among the beneficiaries of the project. Mutually agreed and legally protected benefit-sharing mechanisms are negotiated to ensure implementation

\section{Ensuring Compliance}

Ensuring public trust and confidence requires that governments, developers, regulators and operators meet all commitments made for the planning, implementation and operation of dams. Compliance with applicable regulations, with criteria and guidelines, and with project-specific negotiated agreements is secured at all critical stages in project planning and implementation.

A set of mutually reinforcing incentives and mechanisms is required for social, environmental and technical measures. These should involve an appropriate mix of regulatory and non-regulatory measures, incorporating incentives and sanctions. Regulatory and compliance frameworks use incentives and sanctions to ensure effectiveness where flexibility is needed to accommodate changing circumstances.

- A clear, consistent and common set of criteria and guidelines to ensure compliance is adopted by sponsoring, contracting and financing institutions, and compliance is subject to independent and transparent review.

- A Compliance Plan is prepared for each project prior to commencement, spelling out how compliance will be achieved with relevant criteria and guidelines and specifying binding arrangements for project-specific technical, social and environmental commitments

- Incentives that reward project proponents for abiding by criteria and guidelines are developed by public and private financial institutions 
- Costs for establishing compliance mechanisms and related institutional capacity, and their effective application, are built into the project budget

- Corrupt practices are avoided through enforcement of legislation, voluntary integrity pacts, debarment and other instruments

\section{Sharing Rivers for Peace, Development and Security}

Storage and diversion of water on transboundary rivers has been a source of considerable tension between countries and within countries. As specific interventions for diverting water, dams require constructive co-operation. Consequently, the use and management of resources increasingly becomes the subject of agreement between States to promote mutual self-interest for regional cooperation and peaceful collaboration. This leads to a shift in focus from the narrow approach of allocating a finite resource to the sharing of rivers and their associated benefits in which States are innovative in defining the scope of issues for discussion. External financing agencies support the principles of good faith negotiations between riparian States.

- National water policies make specific provision for basin agreements in shared river basins. Agreements are negotiated on the basis of good faith among riparian States. They are based on principles of equitable and reasonable utilisation, no significant harm, prior information and the Commission's strategic priorities

- Riparian States go beyond looking at water as a finite commodity to be divided and embrace an approach that equitably allocates not the water, but the benefits that can be derived from it. Where appropriate, negotiations include benefits outside the river basin and other aspects of mutual interest.

- Dams on shared rivers are not built in cases where riparian States raise an objection that is upheld by an independent panel. Intractable disputes between countries are resolved through various means of dispute resolution including, in the last instance, the International Court of Justice

- For the development of projects on rivers shared between political units within countries, the necessary legislative provision is made at national and sub-national levels to embody the Commission's strategic priorities of 'gaining public acceptance', 'recognising entitlements' and 'sustaining rivers and livelihoods'

- Where a government agency plans or facilitates the construction of a dam on a shared river in contravention of the principle of good faith negotiations between riparians, external financing bodies withdraw their support for projects and programmes promoted by that agency

\section{A New Focus for Planning and Decision-Making}

The strategic priorities recommended by the Commission lie within a broad framework of existing and emerging policy and regulation at local, national and international levels. (See Figure 3.) Turning these priorities and their underlying principles into reality requires a new focus for planning and management in the water and energy sectors.

This can best be achieved by focusing on the key stages in decision-making that influence final outcomes and where compliance with regulatory requirements can be verified. The Commission has identified five critical decision points when water and energy options are considered. The first two relate to planning, leading to decisions on a preferred development plan:

1. Needs assessment - validating the needs for water and energy services

2. Selecting alternatives - identifying the preferred development plan from among the full range of options

Where a dam emerges from this process as a preferred development alternative, three further critical decision points occur:

3. Project preparation - verifying that agreements are in place before tender of the construction contract

4. Project implementation - confirming compliance before commissioning 
5. Project operation - adapting to changing contexts

Each of the five decision points represents a commitment to actions that govern the course of future conduct and the allocation of resources. They are points where ministries and government agencies need to test compliance with preceding processes before giving the green light to proceed to the next stage. They are not exhaustive, and within each stage many other decisions have to be taken and agreements reached. The five stages and associated decision points need to be interpreted within the overall planning contexts of individual countries. The Commission also noted that even when these decision points have been passed, there are certain steps that should be taken to improve outcomes. ... .

Social, environmental, governance and compliance aspects have been undervalued in decision-making in the past. In light of this, the Commission developed criteria and 26 guidelines to complement the body of knowledge on good practices and to add value to current national and international guidelines, including those on technical, economic and financial aspects. Seen in conjunction with existing decision-support instruments, the Commission's criteria and guidelines provide a new direction for appropriate and sustainable development.

Bringing about this change will require:

- planners to identify stakeholders through a process that recognises rights and assesses risks

- States to invest more at an earlier stage to screen out inappropriate projects and facilitate integration across sectors within the context of the river basin

- consultants and agencies to ensure outcomes from feasibility studies are socially and environmentally acceptable

- all players to promote open and meaningful participation during planning and implementation, leading to negotiated outcomes

- developers to accept accountability through contractual commitments, for effectively mitigating social and environmental impacts

- independent reviewers to improve compliance; and

- dam owners to apply lessons learned from past experiences through regular monitoring and adapting to changing needs and contexts

The Commission offers its criteria and guidelines to help States, developers and owners, as well as affected communities and civil society in general, meet emerging societal expectations when faced with the complex issues associated with dam projects. This will foster informed and appropriate decisions, thereby raising the level of public acceptance and improving development outcomes.

The experience of the Commission demonstrates that common ground can be found without compromising individual values or losing a sense of purpose. But it also demonstrates that all concerned parties must enter into the process in good faith if we are to resolve the issues surrounding water and energy resources development. It is a process with multiple heirs and no clear arbiter. We must move forward together or we will fail.

There will, of course, be further disagreement on these issues. Dynamic debate leads frequently to better outcomes. The Commission believes, however, that business as usual is not a viable strategy. The report closes with a call to action and a challenge to all readers:

\section{Questions \& Discussion}

1. Is the Narmada dam a matter of environmental law, human rights, or economic development? To the extent that all are involved, are the goals compatible or inherently conflicting? If the latter is the case, how can the conflicts be resolved or minimized?

2. After criticism of its support for major environmentally damaging projects, such as the construction of a dam and reservoir in Java between 1985 and 1993 and the Sardar Sarovar dam in India, the World Bank began to plan an increasing role in the field of environmental protection. It established an Inspection Panel in 1993 because of growing concerns about accountability for its work. The Panel is an independent investigatory body receiving complaints issuing from those in the territory of a 
borrower whose rights or interests have been adversely affected by the Bank's failure to comply with its own policies and procedures in the design, appraisal and implementation of a Bank-financed project. The Panel may investigate complaints upon authorization by the Banks Board of Executive Directors, and assess to what extent the bank has complied with its standards. An Inspection Panel Report is reprinted in Chapter 7. 